\title{
MiR-221 Is Specifically Elevated in PC3 Cells and its Deletion Reduces Adhesion, Motility and Growth
}

\author{
D. ALWYN DART ${ }^{1,2}$, SARAH KOUSHYAR $^{1,3}$, BEN E. LANNING $^{1}$ and WENGUO JIANG ${ }^{1}$ \\ ${ }^{1}$ Cardiff China Medical Research Collaborative, Cardiff University School of Medicine, Cardiff, U.K.; \\ ${ }^{2}$ Imperial College London, London, U.K.; \\ ${ }^{3}$ European Cancer Stem Cell Research Institute, Cardiff University, Cardiff, U.K.
}

\begin{abstract}
Background/Aim: MiR-221, often described both as an oncogenic microRNA and as a tumour suppressor, targets $m R N A s$ involved in carcinogenesis. While other oncogenic microRNAs showed correlations with prostate cancer cell lines' aggressiveness, miR-221 showed an unusual overexpression in PC3. Materials and Methods: CRISPR was used to delete miR221 from PC3 cells. Analysing the characteristics of $P C 3^{m i R-}$ 221 del cells, a reduced growth rate and expression of cell-cycle genes was observed. In global gene expression/ontology analysis of $P C 3^{\text {miR-221del }}$ cells, cell-cell and cell-substrate adhesion pathways were found to be greatly affected. In addition, reduced levels of adhesion, invasion and motility for $P C 3^{\text {miR-22ldel }}$ cells, a change in F-actin localisation and a reduction of EMT markers were observed. Results: The tumour suppressor gene, DIRAS3, was a predicted target of miR-221. In PC $3^{\text {miR-221del }}$ cells DIRAS3 was up-regulated at the gene and protein level. Ectopic expression of DIRAS3 in PC $3^{\text {wt }}$ cells recapitulated the cellular morphology changes seen in $P C 3^{m i R}$ 221del cells. DIRAS3 3'UTR was more stable in PC3 $3^{\text {miR-221del }}$ cells, as measured by semi-quantitative PCR and luciferase fusion reporter assays. Conclusion: MiR-221 promotes aggressiveness of PC3 cells by down-regulating DIRAS3, and promoting epithelial-to-mesenchymal transition.
\end{abstract}

Prostate cancer (PCa) is rapidly becoming one of the most common malignancies and a leading cause of cancerassociated mortality in males in the western world (1-3). MicroRNAs (miRs) are involved in many diseases, including prostate cancer, and are being developed as predictive and

This article is freely accessible online.

This article is freely accessible online.

Correspondence to: D. Alwyn Dart, Imperial College London, London, U.K. Tel: +44 2920687069, e-mail: a.dart@imperial.ac.uk

Key Words: MicroRNA, CRISPR, prostate, PC3. prognostic markers of disease, or indeed as therapies $(4,5)$. miRs are short 20-24 nucleotide non-coding RNAs which are involved in post-transcriptional regulation of gene expression by both affecting the stability and translation of mRNAs (68). miRs are transcribed by RNA polymerase II as pri-MiRs, which are then cleaved by the Drosha ribonuclease into a shorter 70-bp sequences named pre-microRNAs which are then further cleaved into mature miRs by the activity of the Dicer ribonuclease. While miR profiling shows that many miRs are differentially expressed in PCa tissues versus the corresponding normal tissues, only a small number of them have been experimentally determined to be involved in the development and progression of PCa.

Evidence suggests that miRs have a central role in controlling basic cell functions as well as several aspects of carcinogenesis - including migration and invasion. MiR expression is frequently altered in cancer, implicating them in the regulation of genes involved in tumour development and progression. The development of metastasis requires cells to acquire migratory and invasive capacities with tumours disseminating cells to distant sites. Migration and invasion are features shared by undifferentiated tumour cells showing traits of epithelial-mesenchymal transition (EMT).

Mir-221 is expressed from a short tandem cluster together with miR-222 located on chromosome $\mathrm{X}$ in both human and mouse, located in an intergenic region of approximately 727 bases. They are homologous, share a seed sequence, and are highly conserved across vertebrate species. Mir-221 has been described as an oncogenic microRNA, overexpressed in many different cancers of epithelial origins and in other diseases. Mir-221 overexpression has been reported for example in glioblastomas $(9,10)$, thyroid (11), breast (12), hepatocellular $(13,14)$ and lung $(15,16)$ cancers. It can target several mRNAs many of which have roles in migration, proliferation, and angiogenesis.

Interestingly the role of miR-221/-222 in $\mathrm{PCa}$, remains debatable and both up- and down-regulation of miR-221/-222 has been reported, especially in CRPC. It is unclear how miR221/-222 are transcriptionally regulated during PCa progression, 
from androgen dependence to castration resistance, and whether miR-221/-222 act as oncogenes (oncomiRs) or tumour suppressor miRs. In studies using clinical tissue samples of PCa compared to either benign, or adjacent tissue, the expression of miR-221 has been found to be reduced - as listed in Table I (1724). Conversely, in clinical studies examining low vs. high grade prostate cancer, miR-221 expression was higher in Gleason grade $>7$ samples (25). In experiments on prostate cancer cell lines (and xenografts) miR-221 has been found to be overexpressed or to have oncogenic properties when overexpressed from oligos/plasmids (Table I, 26-31).

PCa is initially dependent on androgen for growth and is sensitive to androgen deprivation therapy (ADT). However, almost all patients progress to castration-resistant prostate cancer (CRPC). CRPC remains an incurable disease through multiple resistance mechanisms to ADT. The aberrant expression of miRs 221/222 has been correlated with metastatic CRPC and is inversely correlated with the expression of the cyclin dependent kinase inhibitor, p27kip1, in primary prostate cancer $(28-30,32)$. The androgen receptor has been shown to repress the expression of miR$221 / 222$ at the pri-miR level and androgen deprivation therapy may increase miR-221 levels and promote growth (33). Since, highly advanced prostate cancer may not require or depend on $\mathrm{AR}$ for growth then the complexity of miR-221 expression may well be context-dependent.

The apparent discrepancy between cellular and clinical studies seems to be great, especially in the presence of such clear data from clinical studies involving other cancer types. The variability between these studies may be related to different methodology, molecular heterogeneity and sample collection, however, it indicates more inherent differences based on differences in cellular environment e.g. stromal tissue 3D environment to culture cells on tissue culture treated plasticware. We were, therefore, very interested in determining miR-221's role in prostate cancer, especially as it seemed to be one of the highest expressed miRs in the PC3 cell line.

\section{Materials and Methods}

Cell culture. PC3, VCaP, Du145 cells were maintained in DMEM medium (Sigma, Dorset, U.K.), while LNCaP cells were maintained in RPMI medium, all with $10 \%$ foetal bovine serum (First Link, UK), $2 \mathrm{mM}$ L-glutamine, 100 units $/ \mathrm{ml}$ penicillin, $100 \mathrm{mg} / \mathrm{ml}$ streptomycin (Sigma). PNT1A, PZ-HPV7 and CA-HPV-10 cells were maintained in Keratinocyte Serum Free Medium (Sigma), supplemented with bovine pituitary extract $(0.05 \mathrm{mg} / \mathrm{ml})$ and human recombinant epidermal growth factor ( $5 \mathrm{ng} / \mathrm{ml}$, Sigma). HUVEC cells were maintained in Vascular Cell Basal Medium (Sigma) with Endothelial Cell Growth Kit-BBE (Life Technologies, Glasgow, UK). All cells were grown at $37^{\circ} \mathrm{C}, 5 \% \mathrm{CO}_{2}$. All cell lines were obtained from the ATCC cell bank in 2014, and were stored in liquid nitrogen in aliquots. Cells were used within 10 passages of the initial stock.
Invasion assays. Cell invasiveness was assessed using an in vitro Matrigel invasion assay. In brief, transwell inserts containing $8-\mu \mathrm{m}$ pores were placed in a 24-well plate (Nunc, Greiner Bio-One) and coated with $50 \mu \mathrm{g}$ of Matrigel (BD Biosciences, San Jose, CA, USA). Subsequently $2 \times 10^{4}$ cells/insert were added and $1 \mathrm{ml}$ of medium was added to the bottom of the 24-well plate to sustain any invaded cells. The plate was incubated for 3 days at $37^{\circ} \mathrm{C}$ with $5 \%$ $\mathrm{CO}_{2}$ after which inserts were cleaned to remove any non-invaded cells, before cells were fixed in $4 \%$ formaldehyde (v/v) and stained with $0.5 \%$ crystal violet (w/v). Subsequently, invaded cells were visualised under the microscope and representative images captured for analysis.

Adhesion, motility and migration assays. Adhesion assay: Cell suspensions were plated on either normal cell culture treated plastic ware or plates coated with fibronectin, collagen I, or Matrigel. Cells were allowed to adhere for 2-4 h after which the media was washed off and cells were fixed in buffered formalin for $1 \mathrm{~h}$. Cells were washed and stained with crystal violet for microscopy or dissolved in acetic acid (10\% v/v) for spectrophotometric absorbance measurement.

Wound healing assay: Cells were grown in 24-well plates until they had reached a confluent monolayer. A narrow scratch was applied across the monolayer using a sterile pipette tip. Cells were washed and media replaced. Cells were then analysed by microscopy at hourly intervals $(0-8 \mathrm{~h})$ and images captured. Wound area closure was measured using ImageJ software.

Motility assay: Cells were plated at $30 \%$ density and allowed to adhere overnight. Cells were then washed in PBS and the medium was replaced with either normal medium $(10 \%)$ or starvation medium ( $0.5 \%$ FCS). Cells were then imaged at time intervals (20 min) using the Evos microscope (Life Technologies). Cell motility was then measured at intervals, 30 cells per well were followed.

Migration assay: Cells $(500,000)$ were seeded onto the upper chamber of an $8 \mu \mathrm{M}$ ThinCert ${ }^{\mathrm{TM}}$ insert (Greiner-Bio One Ltd, Gloucestershire, UK) in $500 \mu \mathrm{l}$ of medium with $1 \%$ (v/v) FCS. The lower chamber of the 24 well plate contained $1 \mathrm{ml}$ of $10 \%$ FCS RPMI to create a chemoattractant environment. Cells were left to migrate for either 4 or $24 \mathrm{~h}$, depending on the cell type. At the appropriate time point, filters were washed with PBS and placed onto a fresh 24-well plate. An enzyme free cell dissociation solution (Millipore, Hertfordshire, U.K.) $(350 \mu \mathrm{l})$ made with calcein AM (Life Technologies) (ratio of $1.2 \mu \mathrm{l}: 1 \mathrm{ml}$ ) was placed in the lower chamber of the 24-well plate and left to incubate at $37^{\circ} \mathrm{C}$ for one $\mathrm{h}$. The solution was transferred to a black 96-well plate and florescence was measured using the Glomax multi-detection system (Promega Corporation, Madison, WI, USA) at excitation and emission wavelengths of $495 / 515 \mathrm{~nm}$.

ECIS assays. The ECIS Z theta system (Applied Biophysics Ltd, Troy, NJ, USA) was used to evaluate cells' adhesion, migration and their ability to form a monolayer with tight junctions, using ECIS 96-well W96E1 microarrays (Thistle Scientific Ltd, Glasgow, UK). 40,000 cells per well were seeded into wells of the array. Live tracking of cell adhesion was carried out over a range of frequencies from 1,000 to $64,000 \mathrm{~Hz}$ using automated modules for $24 \mathrm{~h}$. All the experiments were conducted at least three times.

RNA extraction and RT. Total RNA samples were prepared using Trizol reagent (Sigma) and converted to cDNA using the GoScript $^{\mathrm{TM}}$ Reverse Transcription System (Promega). RNA quality 
Table I. A selection of in vitro and clinical studies on miR-221 expression and function in prostate cancer, with a summary of the miR-221 predicted function classed as oncomiR or tumour suppressor.

\begin{tabular}{|c|c|c|c|c|}
\hline Study & $\begin{array}{l}\text { Medium \& Analysis } \\
\text { method }\end{array}$ & $\begin{array}{l}\text { Main } \\
\text { findings }\end{array}$ & $\begin{array}{l}\text { Predicted role } \\
\text { of MiR-221 }\end{array}$ & Ref \\
\hline $\begin{array}{l}\text { Normal }(n=20) \text {, ADPC }(n=15) \\
\text { and AIPC }(n=8) \text { patients }\end{array}$ & $\begin{array}{l}\text { Plasma samples } \\
\text { Taqman qPCR }\end{array}$ & $\begin{array}{l}\text { AIPC and ADPC higher than normal } \\
\text { ADPC higher than AIPC }\end{array}$ & $\begin{array}{c}\text { Oncomir } \\
\text { Tumour suppressor }\end{array}$ & (26) \\
\hline $\begin{array}{l}\text { Gleason grade }<7 \text { vs. }>7 \\
\text { (non-agressive } v s . \text { agressive) }(\mathrm{n}=35)\end{array}$ & $\begin{array}{l}\text { SYBR green } \mathrm{qPCR} \\
\text { from tissues }\end{array}$ & $\begin{array}{c}\text { Microrna-221 and } 222 \\
\text { levels significantly higher } \\
\text { in aggressive prostate cancer }\end{array}$ & OncomiR & $(25)$ \\
\hline $\begin{array}{l}\text { Benign, } \mathrm{BPH} \text {, primary and } \\
\text { metastatic } \mathrm{PCa}(\mathrm{n}=4 \text { pairs })\end{array}$ & $\begin{array}{l}\text { Tissue samples } \\
\text { Microarray analysis }\end{array}$ & $\begin{array}{l}\text { Expression of miR-221 is reduced in } \\
\text { aggressive PCa and metastatic deposits. } \\
\text { Correlation to Gleason score }\end{array}$ & Tumour suppressor & (17) \\
\hline $\begin{array}{l}\text { Validated in BPH }(n=9) \text {, } \\
\text { PCa }(n=12) \text {, metastasis }(n=8)\end{array}$ & qPCR & Correlation to recurrence. & & \\
\hline $\begin{array}{l}\text { CRPC }(\mathrm{n}=8) \text { vs. hormone } \\
\text { naive } \mathrm{PCa}(\mathrm{n}=54)\end{array}$ & $\begin{array}{l}\text { Tissue samples } \\
\text { PCR-based array }\end{array}$ & $\begin{array}{l}\text { Significant down-regulation } \\
\text { of miR-221 }\end{array}$ & Tumour suppressor & $(18)$ \\
\hline $\begin{array}{l}\text { Or CRPC }(\mathrm{n}=8) v s . \\
\text { normal prostate }(\mathrm{n}=38)\end{array}$ & & $\begin{array}{c}\text { Low expression of miR-221 } \\
\text { associated with shorter } \\
\text { progression free interval. } \\
\text { MiR-221 did not predict time to CRPC }\end{array}$ & & \\
\hline Cells - PC3 and Du145 & $\begin{array}{l}\text { Cell samples } \\
\text { MiR-221 mimic } \\
\text { overexpression }\end{array}$ & $\begin{array}{l}\text { No inhibition of cell proliferation, } \\
\text { effects on inhibiting cell migration, } \\
\text { invasion significantly inhibited, } \\
\text { no change in apoptosis. }\end{array}$ & & \\
\hline Radical prostatectomy $(\mathrm{n}=153)$ & $\begin{array}{l}\text { Tissue samples } \\
\text { SYBR green qPCR }\end{array}$ & $\begin{array}{l}\text { MiR-221 is down-regulated in patients } \\
\text { with TMPRSS2:ERG fusion. } \\
\text { Down-regulated with metastasis. }\end{array}$ & Tumour suppressor & (19) \\
\hline 2 cohorts A: $(n=134), B:(n=89)$ & $\begin{array}{l}\text { Taqman qPCR on RNA } \\
\text { extracted from } \\
\text { paraffin-embedded tissues. }\end{array}$ & $\begin{array}{l}\text { Down-regulated in PCa compared } \\
\text { to BPH. Independent predictor } \\
\text { for cancer death. }\end{array}$ & & \\
\hline Cells: PC3, Du145 and LNCaP & Mir221 transfection & $\begin{array}{l}\text { PC3/Du145 down-regulation of growth, } \\
\text { LNCaP up-regulation } \\
\text { Reduced invasion, reduced apoptosis }\end{array}$ & Tumour suppressor & $(20)$ \\
\hline Cells: PC3 & $\begin{array}{l}\mathrm{qPCR} \\
\text { Transfections and } \\
\text { reporters }\end{array}$ & $\begin{array}{c}\text { PC3 express high miR-221 } \\
\text { compared to LNCaP } \\
\text { MiR-221 Inhibition showed reduced } \\
\text { proliferation \& migration. } \\
\text { Increased apoptosis }\end{array}$ & Oncomir & $(27)$ \\
\hline Cells: LNCaP and LNCaP-AI & Taqman qPCR & $\begin{array}{c}\text { Up-regulation of miR-221 in AI } \\
\text { Overexpression of miR-221 - reduced } \\
\text { AR transcription, pro CRPC phenotype }\end{array}$ & Oncomir & $(29,30)$ \\
\hline Cells: LNCaP tumours & Tissue and cell lines & $\begin{array}{l}\text { Ectopic overexpression miR-221 } \\
\text { confers high growth advantage to LNCaP } \\
\text { Inhibition in PC } 3 \text { - reduces tumour growth }\end{array}$ & Oncomir & $(31)$ \\
\hline $\begin{array}{l}\text { Patients: stage II-III }(n=21) \text { primary } \\
\text { samples taken for cell culture. }\end{array}$ & Taqman qPCR & $\begin{array}{l}\text { Up-regulation in patients } \\
\text { derived cell lines. }\end{array}$ & & \\
\hline $\begin{array}{l}\text { BPH }(n=4) \text { PCa }(n=9) \\
\text { Cell lines }(n=6) \text {, xenografts }(n=9)\end{array}$ & $\begin{array}{l}\text { Tissue, cell lines, xenografts } \\
\text { SYBR green qPCR }\end{array}$ & $\begin{array}{l}\text { MiR-221 down-regulated } \\
\quad \text { in all carcinomas }\end{array}$ & Tumour suppressor & $(21)$ \\
\hline Pooled PCa samples vs. normal $(\mathrm{n}=5)$ & $\begin{array}{c}\text { Tissues } \\
\text { Deep sequencing }\end{array}$ & MiR-221 down-regulated & Tumour suppressor & $(22)$ \\
\hline $\begin{array}{l}\text { Primary }(n=60) \text { and } \\
\text { Non-tumour }(n=16)\end{array}$ & $\begin{array}{l}\text { Tissues } \\
\text { qPCR }\end{array}$ & MiR-221 down-regulated & Tumour suppressor & $(23)$ \\
\hline PCa samples $(n=20)$ & $\begin{array}{l}\text { miRNA microarrays } \\
\qquad \& \text { qPCR }\end{array}$ & MiR-221 down-regulated & Tumour suppressor & $(24)$ \\
\hline
\end{tabular}

was assessed using a Bioanalyser 2100 (Agilent, Santa Clara, CA, USA). For MicroRNA RT-qPCR, 10 ng of total RNA was reverse transcribed using the TaqMan ${ }^{\mathrm{TM}}$ Advanced miRNA cDNA Synthesis Kit (Life Technologies).
$Q-P C R$. Reactions were performed in triplicate in 96-well optical plates on an ABI One-Step system (Applied Biosystems, Warrington, U.K.), consisting of $2 \mu \mathrm{l}$ cDNA, $7 \mu \mathrm{l}$ PCR-grade water, $10 \mu 12 \times$ TaqMan Universal PCR Master Mix (Applied Biosystems), 
$1 \mu$ Taqman specific assay probes (Applied Biosystems) for DIRAS3, RPL19, $\beta$-actin, and GAPDH. Parameters were: $50^{\circ} \mathrm{C}$ for $2 \mathrm{~min}, 95^{\circ} \mathrm{C}$ for $10 \mathrm{~min}, 40$ cycles of $95^{\circ} \mathrm{C}$ for $15 \mathrm{sec}$ and $60^{\circ} \mathrm{C}$ for 1 min. Data was recorded using Sequence Detector Software (Applied Biosystems) and normalised to GAPDH, $\beta$-actin and RPL19.

MicroRNA-seq analysis. Total RNA was isolated from PC3 cells using the mirVana miRNA Isolation Kit (Thermofisher, Waltham, MA, U.S.A.), following a protocol to enrich for small RNAs $<200$ bp. This was verified using a Bioanalyser-2100 (Agilent). RNA fragment libraries (150-200 bp) were generated using the Nextflex Small RNA sequencing kit (Perkin Elmer, Waltham, MA, USA) and ligated to adapters for cDNA synthesis. cDNA was then amplified using barcoded primers (5') and quantified with a Qubit assay (Life Technologies).

cDNA libraries were clonally amplified by emulsion PCR on Ion Sphere Particles (ISP's) using Ion PI template OT2 200 kit (Life Technologies) on an Ion OneTouch2 system (Life Technologies) as per manufacturer's instructions. The template positive ISP's were recovered and enriched to remove non-template ISP's on Ion One Touch ES (Life Technologies). The ISPs were processed using the Ion Proton 200 sequencing kit and loaded onto a P1 chip and sequenced on an Ion Proton (Life Technologies) using default parameters (single-end, forward sequencing). Base calling, adaptor trimming, barcode deconvolution and alignment was performed on Torrent Suite version 3.6 (Life Technologies) using the STAR RNAseq aligner plugin. The Partek Genomic Suite 6.6 software was used for data analysis.

Ampliseq (RNA-seq). Total RNA was isolated from cells using Trizol (Sigma) and DNase treated before use. The IonAmpliseq ${ }^{\mathrm{TM}}$ Transcriptome Human Gene Expression kit (Life Technologies) was used for reverse transcription to cDNA. The Human Gene Expression Core Panel primer set (Life Technologies) was then used to prepare small amplicon gene expression libraries targeting 20,000 genes (95\% of the RefSeq gene database). Protocols were followed according to manufacturer's protocols.

The cDNA amplicon libraries (125-300 bp) were ligated to adapters and amplified using IonXpress RNA-seq barcoded primers (5'). cDNA libraries were clonally amplified using Ion PI template OT2 200 kit (Life Technologies, USA) on an Ion OneTouch2 system (Life Technologies) as per manufacturer's instructions. Samples were processed using the Ion Proton 200 sequencing kit and loaded onto a P1 chip and sequenced on an Ion Proton (Life Technologies) using default parameters (single-end, forward sequencing). Base calling, adaptor trimming, barcode deconvolution, alignment and Ampliseq gene expression analysis was performed on Torrent Suite version 3.6 (Life Technologies) using the STAR RNA-seq aligner plugin.

Donor plasmid generation. The homologous recombination plasmid (pHR110PA-1) was obtained from Cambridge Bioscience, Cambridge, UK. The genomic regions representing $1 \mathrm{~kb}$ downstream and $1 \mathrm{~kb}$ upstream of the mir-221 genomic locus (representing the mature miRNA coding region) were amplified by PCR and ligated into the pHR110PA-1 plasmid sequentially i, right homology arm into BamH1/Sph1 sites and then ii, left homology arm into the EcoR1/BglII sites. Left homology arms primers 5'[GAGCTC]CCATTATTACATGTAGACATTTATC-3' and 5' -[AGA
TCT]GCTACCTGGAAACATGTTCT-3' and right homology arm primers 5'-[GGATCC]ATGTTCAGCTTGCAAGTAATTCT-3' and 5'-[GCATGC]CCAGAAGGCAAAGGATCA-3'. This generated the pHR110PA-1 miR221-HDR plasmid. Sequences were verified by sequencing and restriction mapping.

gRNA plasmid generation. The pSpCas9(BB)-2A-GFP (PX458) plasmid was a gift from Feng Zhang (Addgene plasmid \# 48138). Several gRNA plasmids targeting potential sites across the mir-221 region were generated. Briefly the guide sequence oligos were designed using CRISPR gRNA design tool (Life Technologies) and synthesized from MWG-Eurofin Ltd, Ebersberg, Germany. These were annealed and ligated into the sgRNA scaffold at the $B b s 1$ site using the following structure 5'-CACCG(N) $19^{-3}$ ' and 5'$\operatorname{AAAC}(\mathrm{N}){ }_{19} \mathrm{C}-3$ '.

Transfection. PC 3 cells were transfected with pHR110PA-1 miR221 and gRNA (pX458) simultaneously and allowed to grow for $24 \mathrm{~h}$, after which they were treated with $1 \mathrm{ug} / \mathrm{ml}$ puromycin. Cells were then plated out and diluted on a 96-well plate as single cells/well, and individual colonies were isolated and expanded. Plasmid integration and recombination events were validated by genomic PCR and fluorescence microscopy, with $100 \%$ of cells showing RFP fluorescence in the expanded cell lines. Mir-221 expression was then analysed by Q-PCR. Individual miR-221 knockout clones were then recombined as a multi clonal mixed cell line.

Generation of a DIRAS3 mammalian expression vector. The fulllength coding region of DIRAS3 was amplified from PC3 cDNA using the primers: For 5'-ATGGGTAACGCCAGCTTTGG-3' and Rev 5'-TCACATGATTATGCACTTGTCAAGCA-3'. The PCR amplification product was ligated into pEF6-TOPO vector (Life Technologies), and confirmed by sequencing and directional PCR. The plasmids were transfected into PC3 cells with Lipofectamine 3000 (Life Technologies).

Generation of a DIRAS3 3'UTR luciferase reporter \& activity assays. The 3'UTR sequence of DIRAS3 (645 bp) containing the miR221/222 sites was PCR amplified from PC3 cDNA using the primers: For 5'-[GAGCTC]GCCCTGGGCCTTAAGAGC-3' and Rev 5'-[GTCGAC]TGCATGCAGGAAAAGCTTTATTAAGTC-3'. The PCR product was digested with $S a c 1$ and Sal1 and ligated into the pMiR-Glo vector (Promega).

The plasmids were transfected into PC3 cells with Lipofectamine 3000 (Life Technologies) and luciferase assays carried out $24 \mathrm{~h}$ later using the Stop and Glo assay kit for firefly and renilla luciferase (Promega). Luciferase activity was normalised to renilla activity.

\section{Results}

Analysis of the microRNA expression profile of the PC3 prostate cancer cell line. PC3 cells represent highly aggressive prostate cancer. The cell line grows rapidly in culture and in vivo xenografts, where it spontaneously forms metastatic lesions. Additionally, the cell line does not express androgen receptor and is completely androgen independent. PC3 cells are also negative for several luminal differentiation markers, and show some (but not all) similarities with small cell neuroendocrine carcinomas (SCNC) (34). Total RNA 
A

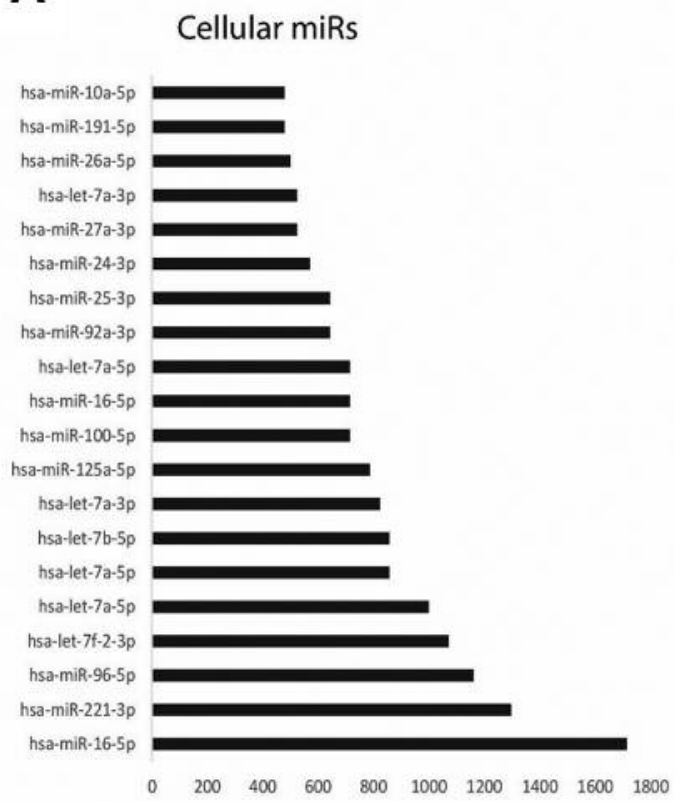

C

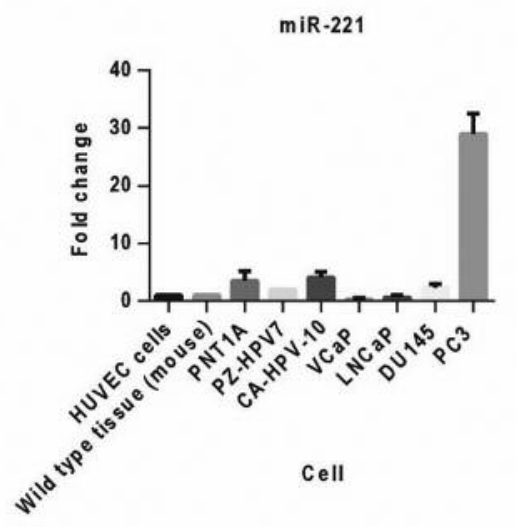

miR-125a

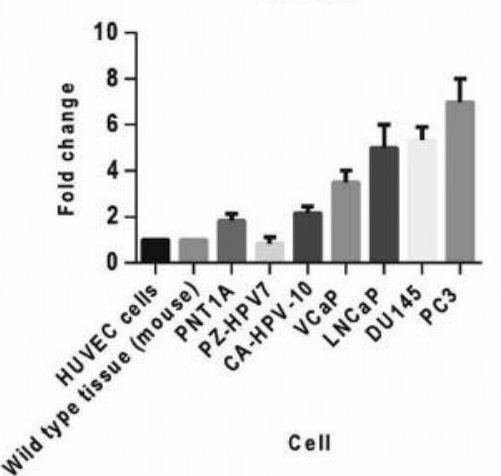

B

\begin{tabular}{|c|c|c|c|c|c|}
\hline $\begin{array}{l}\text { Cell line/ } \\
\text { tissue }\end{array}$ & Immortalised & Derived from & AR expression & $\begin{array}{l}\text { Tumourigenic } \\
\text { in nude mike }\end{array}$ & $\begin{array}{c}\text { Metastatic } \\
\text { potential in } \\
\text { nude mice }\end{array}$ \\
\hline HUVEC & No & $\begin{array}{c}\text { Normal } \\
\text { human } \\
\text { umblical cord }\end{array}$ & NA & No & No \\
\hline $\begin{array}{c}\text { Mouse } \\
\text { prostate } \\
\text { tissue }\end{array}$ & No & $\begin{array}{l}\text { Normal } \\
\text { mouse } \\
\text { prostate } \\
\text { tissue }\end{array}$ & Yes & No & No \\
\hline PNT1A & svao & $\begin{array}{c}\text { Normal } \\
\text { humanan } \\
\text { prostate } \\
\text { epithelal cells }\end{array}$ & Yes & No & No \\
\hline PZ-HPV-7 & HPV18 & $\begin{array}{c}\text { Normal } \\
\text { human } \\
\text { prostate } \\
\text { opithelial colls }\end{array}$ & Yes & No & No \\
\hline CA-HPV-10 & HPV18 & $\begin{array}{l}\text { Prostate } \\
\text { adencoarcino } \\
\text { ma (Gieason } \\
4+4) \\
\text { (4) }\end{array}$ & Yes & No & No \\
\hline vcap & $\begin{array}{l}\text { Yes.- } \\
\text { Spontaneous }\end{array}$ & 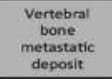 & $\begin{array}{l}\text { Yes. } \\
\text { overexpressio } \\
n\end{array}$ & Yes & Not reported \\
\hline LNCAP & $\begin{array}{l}\text { Yes- } \\
\text { Spontaneous }\end{array}$ & $\begin{array}{l}\text { Lymph node } \\
\text { metastatic } \\
\text { deposit }\end{array}$ & $\begin{array}{l}\text { Yes - mutant } \\
\text { T8777 A }\end{array}$ & Yes & Low tendency \\
\hline Du145 & $\begin{array}{l}\text { Yes- } \\
\text { Spontaneous }\end{array}$ & $\begin{array}{c}\text { Brain } \\
\text { metastictic } \\
\text { deposit }\end{array}$ & No & Yes & $\begin{array}{l}\text { Moderate } \\
\text { tondency }\end{array}$ \\
\hline PC3 & $\begin{array}{l}\text { Yes- } \\
\text { Spontaneous }\end{array}$ & $\begin{array}{c}\text { Prostatic } \\
\text { adenocarcino } \\
\text { ma }\end{array}$ & No & Yes & Metastatic \\
\hline
\end{tabular}

miR-16

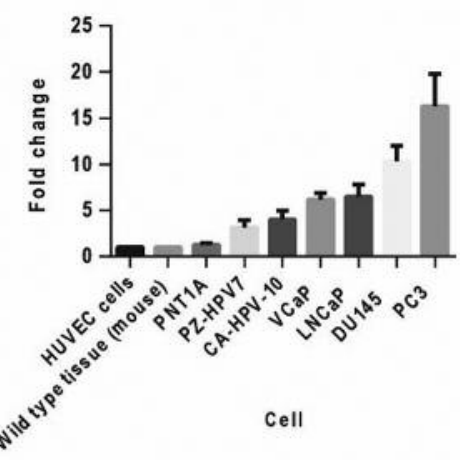

miR-27a

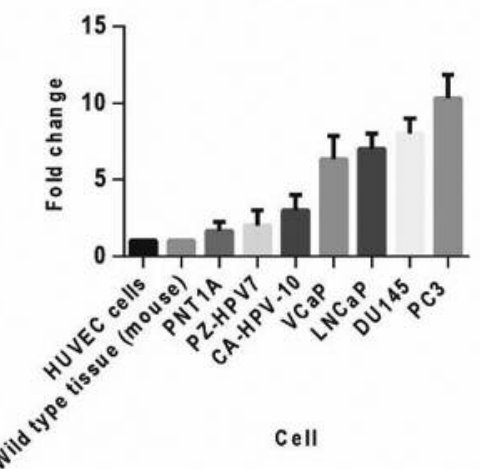

Figure 1. MiR-221 is the second highest expressed miR in PC3 cells. A) MiR-Seq analysis of miR expression from PC3 cells - graph shows the top 20 highest expressed miRs. Data is given as reads per million. B) Table showing the characteristics of the prostate cell line panel used in this study. Cell lines have been ordered according to apparent aggressive tendency (by our own parameters as indicated). C) Q-PCR analysis of miRs 221, 16, $125 a$ and 27 a expression in a panel of prostate cell lines, ranked according to the characteristics in the Table. Data is normalised to U6 and U8 small nuclear RNAs and then normalised to HUVEC cells. Graphs represent three independent replicates. 
was isolated from PC $3^{\text {wt }}$ cells and was subjected to RNA size fractionation to isolate $<200 \mathrm{bp}$ RNA species. The miRs were then sequenced using the NextFlex miR sequencing kit. The total miR expression of PC3 was analysed and normalized using Partek Genomics Suite. Analysis of miR expression content indicated that hsa-miR-221-3p was the second most strongly expressed miR in PC3 cells (Figure 1A), after hsa-miR-16-5p.

Various studies have indicated that miR-221 functions both as an oncogene and a tumour suppressor. Additionally, in clinical samples miR-221 has been found to be lost or down-regulated, and in vitro studies have shown that miR221 is correlated with increased growth and invasiveness and with the development of androgen independence. Table I presents a sample of clinical and in vitro studies which show the apparent disparity in relation to miR-221. Such in vitro studies have classically been carried out with exogenous miR mimics or inhibitors and as such represent an artificial system where oligonucleotide manipulation may promote other off target effects. Here, we have investigated the genetic deletion of the mature miR-221 nucleotide from the genome using CRISPR technology.

Analysis of miR expression across a panel of prostate cancer cell lines. MiR-221 expression was analysed in a panel of prostate cell lines. We utilized human HUVEC cells (Human Umbilical Vein Endothelial Cells) as a control for normal nonimmortalised human cells to give a baseline for miR expression/comparison. Additionally, mouse normal prostate tissue was used since fresh human normal prostate tissue was unavailable. Cells and tissues were ranked in order of aggressiveness according to our own criteria - comparing tissue derivation, immortalization, tumourigenicity and metastatic potential in nude mice (Figure 1B). The oncomiRs mir-27a, miR-155 and miR-16 were found to have a strong correlation with aggressiveness across our panel, whereas miR-221 only showed a high expression level in PC3 cells (Figure 1C).

Generation of a miR-221 knock out cell line. As miR-221 was one of the most abundant miRs expressed in PC3 cells and was much higher in PC3 than other cell lines, we decided to use a CRISPR/Cas9 system to delete/ remove the miR-221 genomic sequence from chromosome $\mathrm{X}$ of PC3 cells. PC3 cells were transfected with the pHR110PA-1 miR221-HDR plasmid and the pX458 targeting plasmid (gRNA and CRISPR) (Figure 2A). Cells were grown with puromycin selection and $\mathrm{RFP}^{+\mathrm{ve}} \mathrm{PC} 3$ cells were isolated and expanded. Genomic recombination events were verified by genomic DNA extraction and PCR (Figure 2B), and RFP expression was seen in all cells to some degree (Figure 2C). The levels of miR-221 became undetectable when assayed by qPCR analysis $(<1 \%)$ (Figure $2 \mathrm{D})$. The co-expressed miR-222 was also greatly reduced down to $<16 \%$.
Henceforth the parental PC3 cell line will be called PC $3^{\mathrm{wt}}$ and the CRISPR knock out labelled PC $3^{\text {miR-221del. }}$

MiR-221 knock out decreases cell growth. To ascertain the effects of miR-221 knock out on PC3 cell growth and functional characteristics several parameters were assessed. Firstly, using an MTT assay for cell growth, we noticed that the growth rate of $\mathrm{PC} 3^{\mathrm{miR}-221 \mathrm{del}}$ cells was slightly reduced (Figure 3A). Additionally, when equal number of cells were grown over 6 days and collected daily for FACS analysis, $\mathrm{PC} 3^{\mathrm{wt}}$ cells were found to grow faster and reached confluency sooner, whereas the number of cycling cells was higher in $\mathrm{PC} 3^{\mathrm{miR}-221 \mathrm{del}}$ cells, which did not yet reach confluency (Figure 3B and C). When analysing cell cycle specific genes in cells grown during the normal growth phase, the DNA replication genes, MCM3-10 genes, were expressed less in PC $3^{\text {miR-221del }}$, and the cell cycle dependent kinase inhibitor genes CDKN1A and CDK2A were upregulated (Figure 3D) compared to $\mathrm{PC} 3^{\mathrm{wt}}$ cells.

MiR-221 knock out reduces motility and invasion of PC3 cells. We analysed the phenotypic characteristics of the PC $3^{\text {miR-221del }}$ cells compared to the PC $3^{\text {wt }}$ cells in several assays. Migration of cells was assessed using a transwell migration assay. PC $3^{\text {miR-221del }}$ cells showed less migration than the PC $3^{\text {wt }}$ cells (Figure 4A). Additionally, PC $3^{\text {miR-221del }}$ cells showed less invasive potential in a similar transwell invasion assay through a matrigel layer (Figure 4B).

We monitored the random directional motility of PC3 cells under normal growth conditions in $10 \%$ serum and in reduced serum $(<0.5 \%)$. In reduced serum neither the $\mathrm{PC} 3^{\mathrm{wt}}$ nor PC $3^{\text {miR-221del }}$ cells showed any significant movement, but with added serum, PC $3^{\text {wt }}$ cells showed a statistically significant increase in movement distance as expected. However, no significant increase in motility was seen in the PC3 ${ }^{\text {miR-221del }}$ cells (Figure 4C).

We then measured migration and rate of adhesion to form a monolayer using the Electric cell-substrate impedance sensing system (ECIS). As cells adhered and formed a monolayer over $5 \mathrm{~h}$ (approx.) the electrical impedance increase was measured. PC $3^{\text {miR-221del }}$ cells showed a statistically lower electrical resistance, initially, for the first 1$2 \mathrm{~h}$ and then showed no real difference after $4 \mathrm{~h}$ (Figure 4D).

We monitored the cell migration and cell-cell interaction by the scratch/wound healing assay. Over 8-10 h the PC $3^{\mathrm{wt}}$ cells closed the wound completely, whereas the PC $3^{\mathrm{miR}-}$ 221del cells had not. The PC $3^{\text {miR-221del }}$ cells showed a delayed wound closure, as after a lag of 2-3 h the velocity of wound closure was the same as for the parental cell line (Figure 4E and F).

Mir-221 knock out reduces the rate of cell adhesion. We analysed the rate of adhesion of the cells to a cell culture 
A

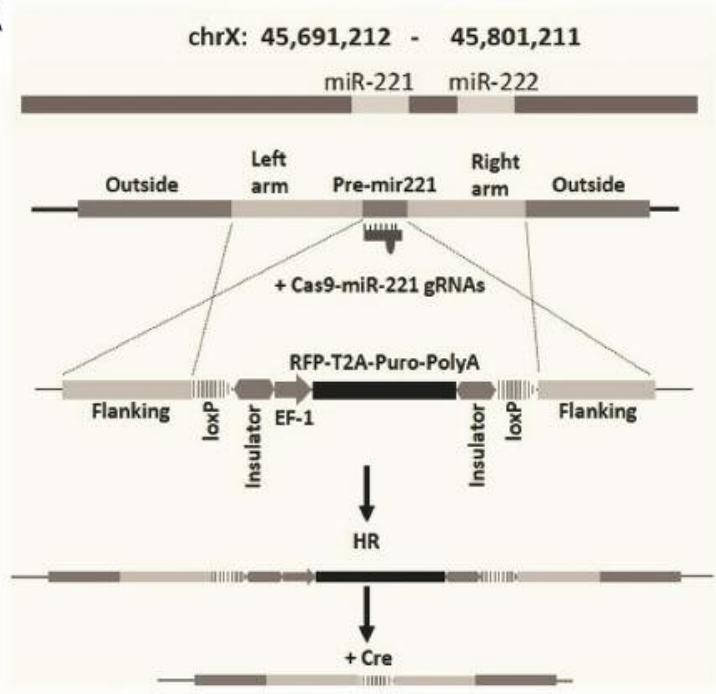

C

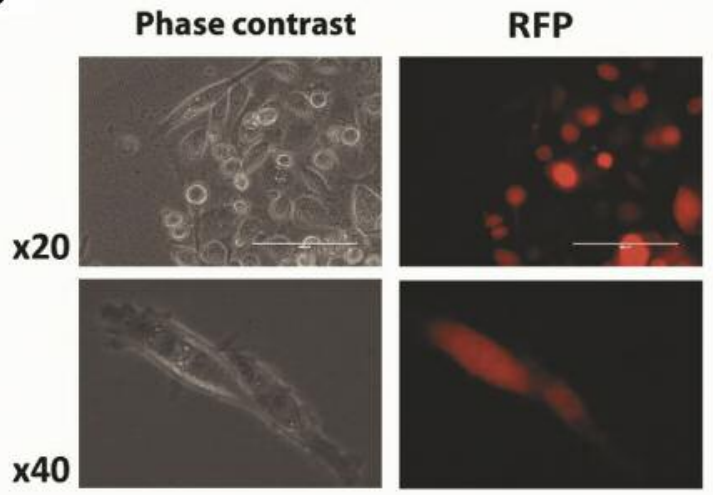

B
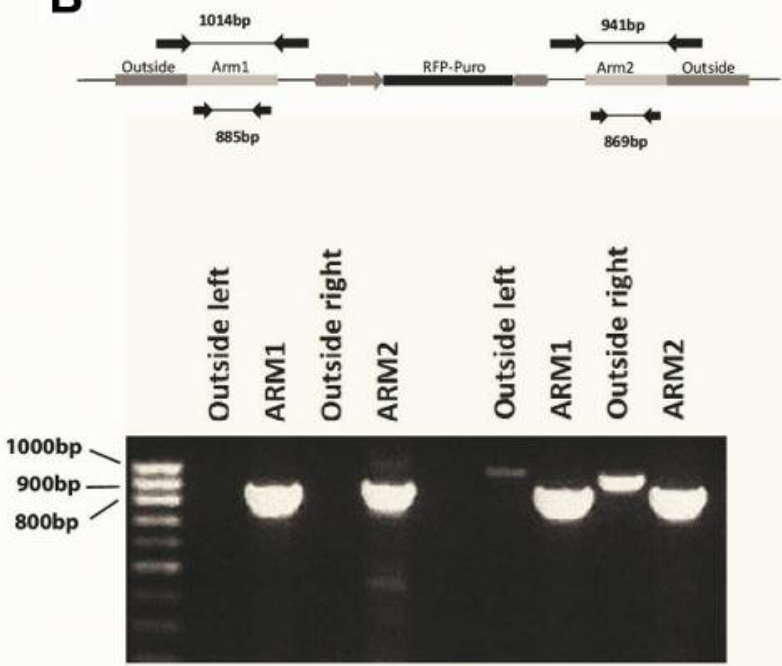

PC3 wt

D

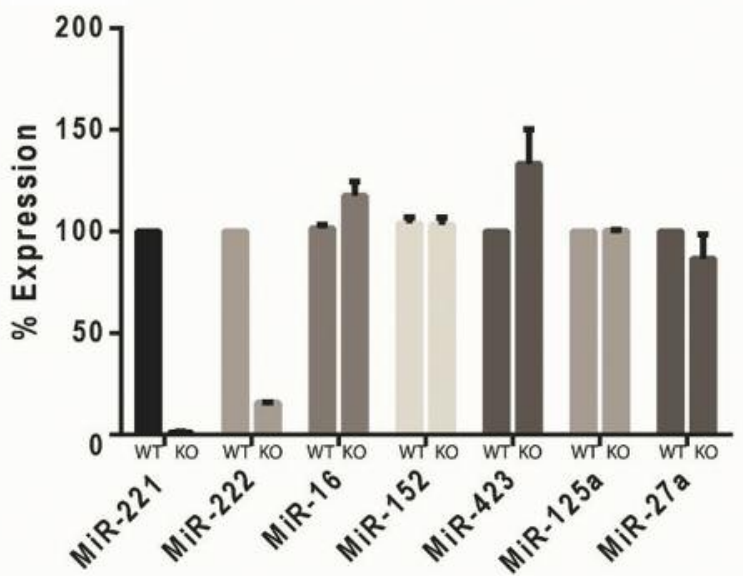

Figure 2. Genomic deletion of miR-221 from PC3 cells using CRISPR and homologous recombination. A) Schematic diagram of the miR-221/222 locus on chromosome $X$, including the recombination vector designed with $1 \mathrm{~kb}$ homology arms upstream (Left arm) and downstream (Right arm) and the CRISPR DNA cleavage gRNA. After strand cleavage DNA homology repair is guided by the donor plasmid which inserts loxP sites, RFP and puromycin selection. After homologous recombination the RFP and puromycin markers are removed via Cre recombinase. B) Upper panelschematic of predicted PCR amplification fragments following genomic recombination events. Lower panel - gel PCR of the homologous recombination events in PC $3^{w t}$ and PC $3^{m i R-221 d e l}$ genomic DNA. C) Phase contrast and fluorescence microscopy of clonal PC $3^{m i R-221 d e l}$ cells showing RFP expression in all cells. D) Q-PCR analysis for miR expression from PC $3^{\text {wt }}$ and PC $3^{m i R-221 d e l}$ cells. Data represents the mean of three independent replicates, and is normalised to U6 \& U8 small nuclear RNAs. Data is also normalised to PC3 expression.

vessel. Cells from a suspension were allowed to adhere onto the surface for $2 \mathrm{~h}$, after which cells were washed with PBS and fixed in formaldehyde solution. Plates were either noncoated, or coated with fibronectin or matrigel. Cells were then stained using crystal violet solution and visualized under a microscope, and counted (Figure 5A). On standard tissue culture plastic dishes, or on fibronectin or Matrigel, $\mathrm{PC} 3^{\mathrm{miR}-}$
$221 \mathrm{del}$ cells showed a reduced number of adhered cells in this time (Figure 5A). The cells also showed a phenotypic morphological change in shape, being more rounded and larger in appearance. Cells appeared less adherent and less well spread out on the surface. In many cells there was an absence of a prominent leading lamellopodia or trailing edge (see figure 5A and B). We then stained the cells with FITC- 
A

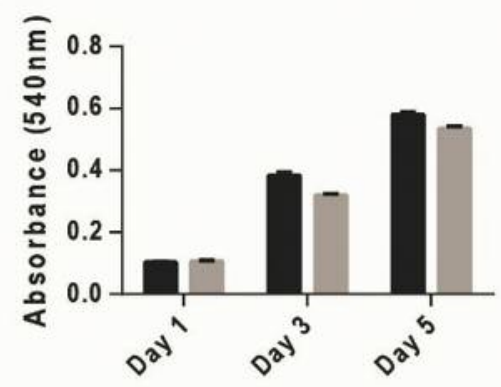

C

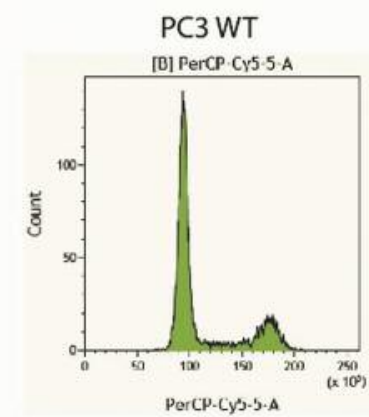

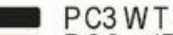

PC3 miR221 del

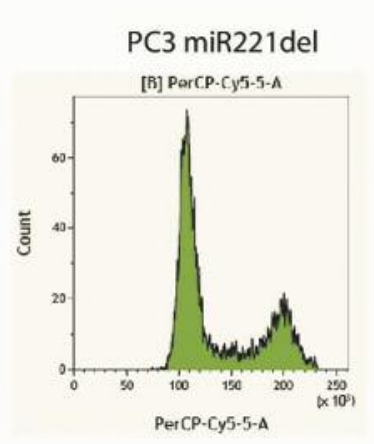

B

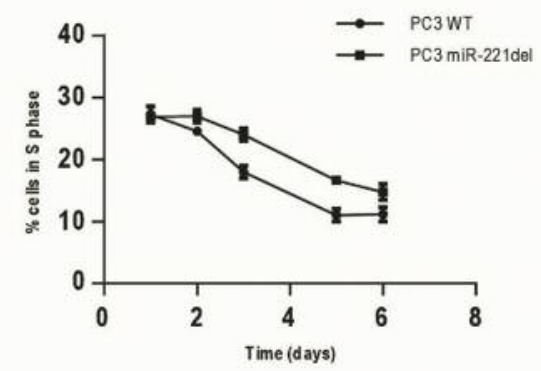

D

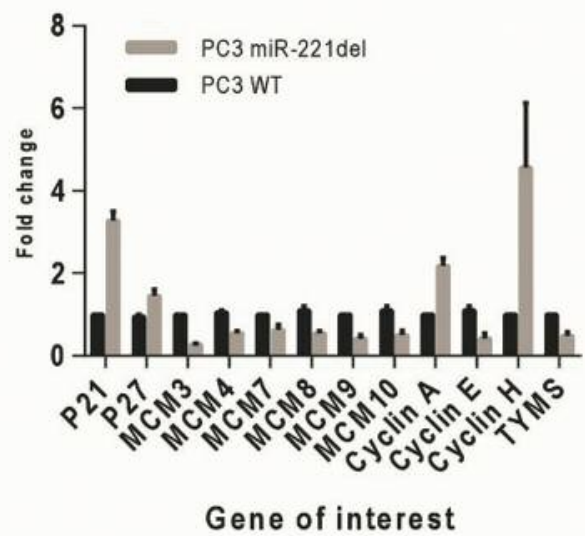

Figure 3. MiR-221 deletion reduces cell cycle kinetics and cellular replication. A) Bar graph indicating cell growth and viability of PC3wt and PC 3miR-221del cell over 5 days, as measured by the MTT cell viability assay. B) Graph indicating \% of cells in $S$ phase as measured by FACS analysis for cell cycle distribution. PC $3^{w t}$ and PC $3^{m i R-221 d e l}$ cell were grown for six days. C) Cell-cycle distribution histograms of PC ${ }^{w t}$ and PC $3^{m i R-221 d e l}$ cells at day 6 of growth. $X$ axis represents propidium iodide fluorescence units. D) Q-PCR analysis of various cell cycle regulators and DNA replication genes in PC $3^{w t}$ and PC $3^{m i R-221 d e l}$ cells. Data normalised to GAPDH, $\beta$-actin and RPL19.

conjugated phalloidin to visualize cellular F-actin localisation. In the larger rounded cells, F-actin was seen to localise in the periphery of the cytoplasm (Figure 5B). Conversely, PC $3^{\mathrm{miR}-}$ $221 \mathrm{del}$ cells showed an increase adhesion to collagen coated dishes (Figure 5A), but this did not translate into increased invasiveness through the collagen. PC $3^{\text {miR-221del }}$ cells showed very poor adhesion to glass slides, even after $24-48 \mathrm{~h}$.

Mir-221 deletion affects genes involved in cell-cell adhesion in PC3 cells. We then went on to verify if miR-221 knock out affected proteins involved in cell adhesion, motility and cellcell binding. A simplified schematic diagram of genes involved in the epithelial-mesenchymal transition (EMT) are given in Figure 6A. Protein levels were determined using western blotting. We analysed proteins with known roles in cellular adhesion either cell-cell adhesion $e . g$. tight junction proteins or cell-substrate adhesion e.g. focal adhesions. Ecadherin, Occludin, ZO-1 and JamB protein levels were upregulated in $\mathrm{PC} 3^{\mathrm{miR}-221 \mathrm{del}}$ whereas vimentin, nectin3, were down-regulated. MMP1 showed up-regulation in $\mathrm{PC} 3{ }^{\mathrm{miR}-}$ 221del (Figure 6B). Eplin and Rock2 were seen to be upregulated, whereas no change was seen in FAK and MMP9 (Figure 6B).

PC $3^{\text {miR-221del }}$ cells show changes in gene expression. Since miRs regulate expression of mRNAs in cells via influencing strand stability, we utilised an Ampliseq methodology for gene expression analysis. The deletion of miR-221 resulted in a change of expression of over 1000 genes [approx. 646 significantly down-regulated genes and 534 up-regulated genes $(-/+2$-fold change, $p=0.05)]$. When analysed via IPA Ingenuity software the main pathways affected by these gene changes were associated with adhesion, cell-cell binding, trans-endothelial migration and mobilization of calcium. These pathways agreed well with the observed changes in the adhesion observed (Table II). However, no specific global correlations could be made between gene expression and miR-221 predicted targets (data not shown). 

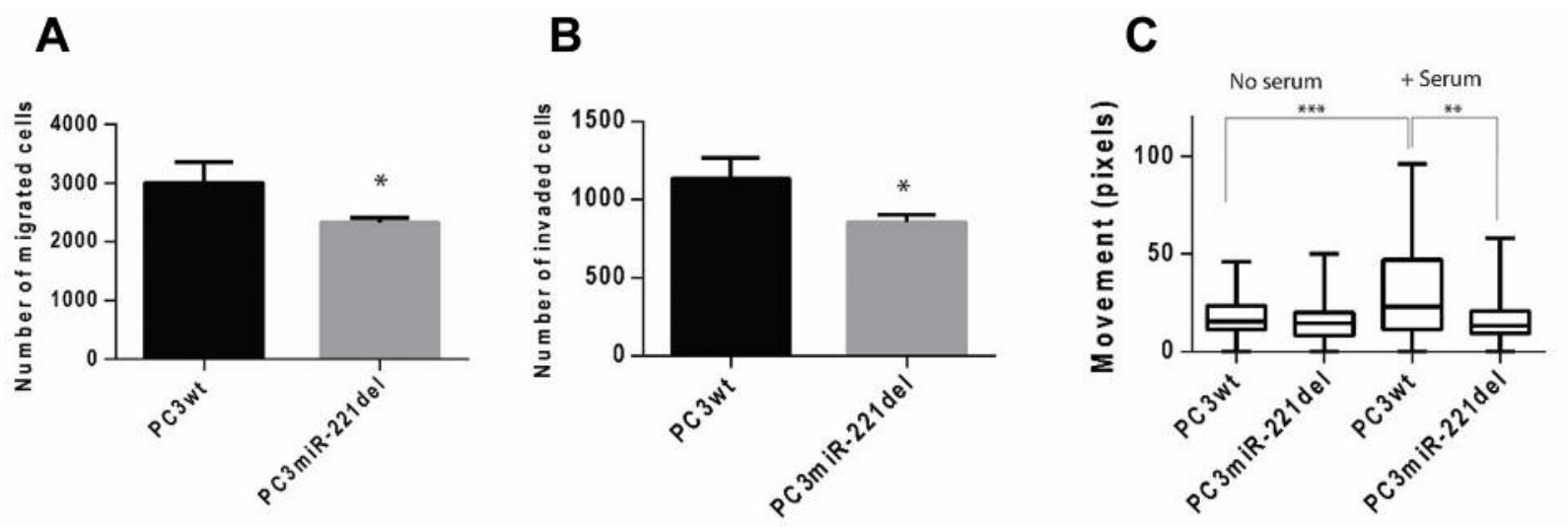

D
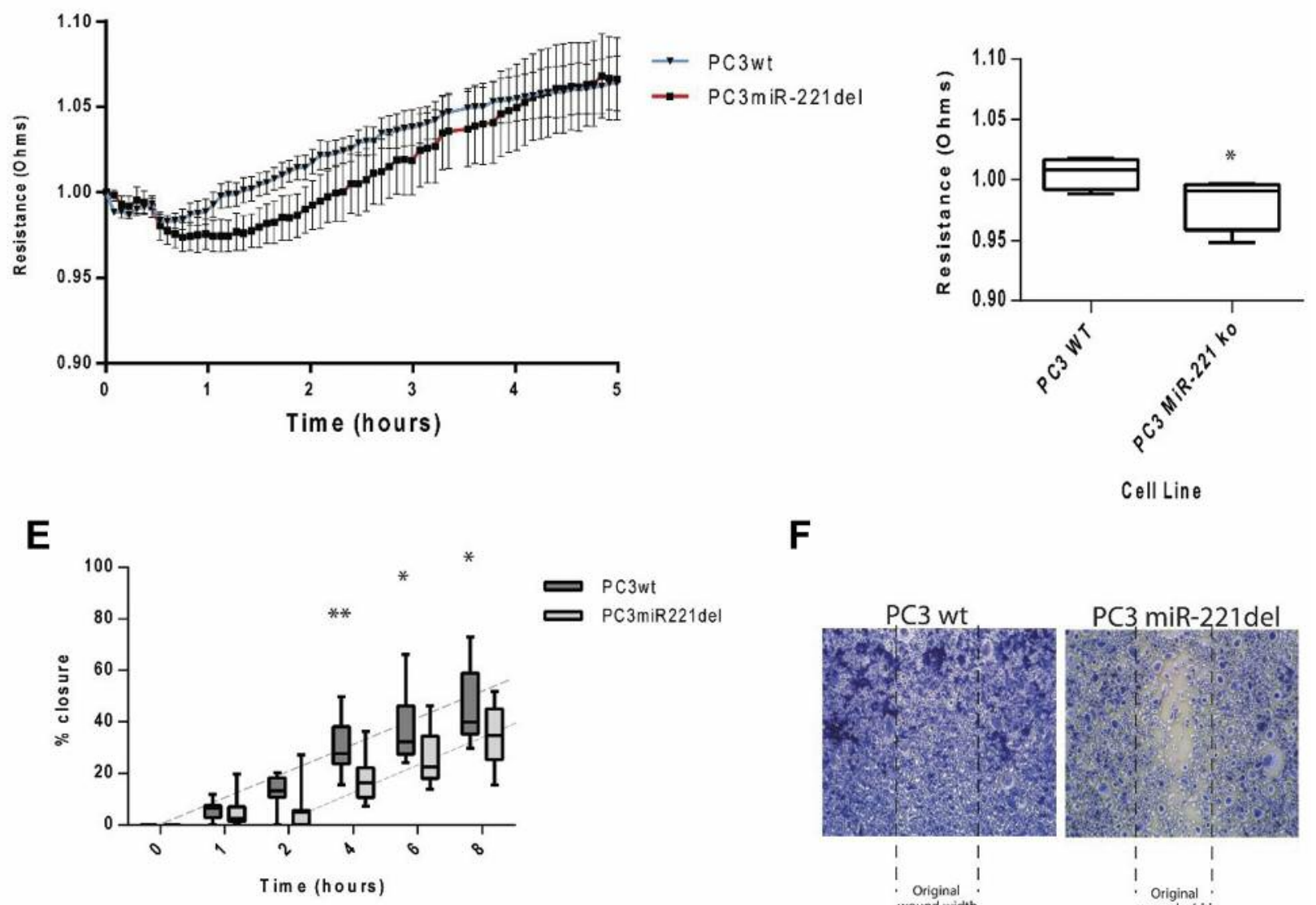

$\mathbf{F}$
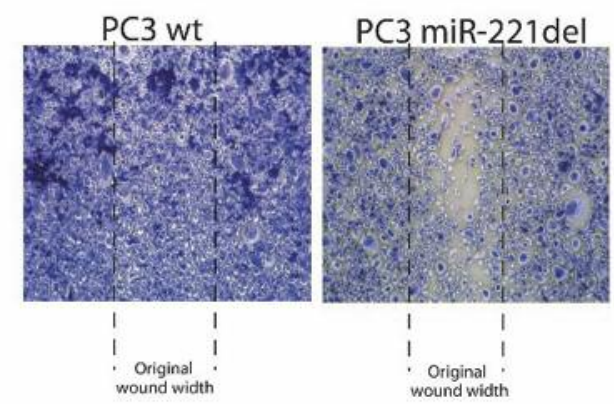

Figure 4. MiR-221 deletion reduces migration, motility, invasion and adhesion of PC3 cells. A) Bar graph indicating the number of PC $3^{w t}$ and PC $3^{m i R-}$ $221 d e l$ cells migrated across a membrane in 24 h. B) Bar graph indicating the number of PC $3^{w t}$ and PC $3^{m i R-221 d e l}$ cells invading through a matrigel

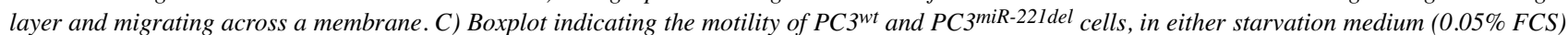
or full medium (10\% FCS) for 8 h.D) Graph indicating the resistance and electrical impedance of PC $3^{w t}$ and PC3miR-22Idel cells adhering to the ECIS assay plate over 5 h. Boxplot (inset) represents the resistance as measured at $1.5 \mathrm{~h}$. E) Boxplot representing the \% closure of a scratch (wound healing) assay of PC $3^{w t}$ and PC $3^{m i R-221 d e l}$ cells over 8 h.F) Grayscale photograph of the PC3 cells at the $8 \mathrm{~h}$ time index. * $p=0.05, * * p=0.01$.

The DIRAS3 tumour suppressor is a target of miR-221/222. From the IPA analysis, the main predicted upstream target of mir-221 was DIRAS3 (ARH1) (Table III). DIRAS3 is a tumour suppressor gene that is frequently down-regulated in cancer. It is also a target of miR-222, therefore represents an interesting target molecule. When we analysed DIRAS3 expression levels in PC $3^{\text {miR-221del }}$ cells we saw an almost 10 -fold increased expression at the mRNA level when 

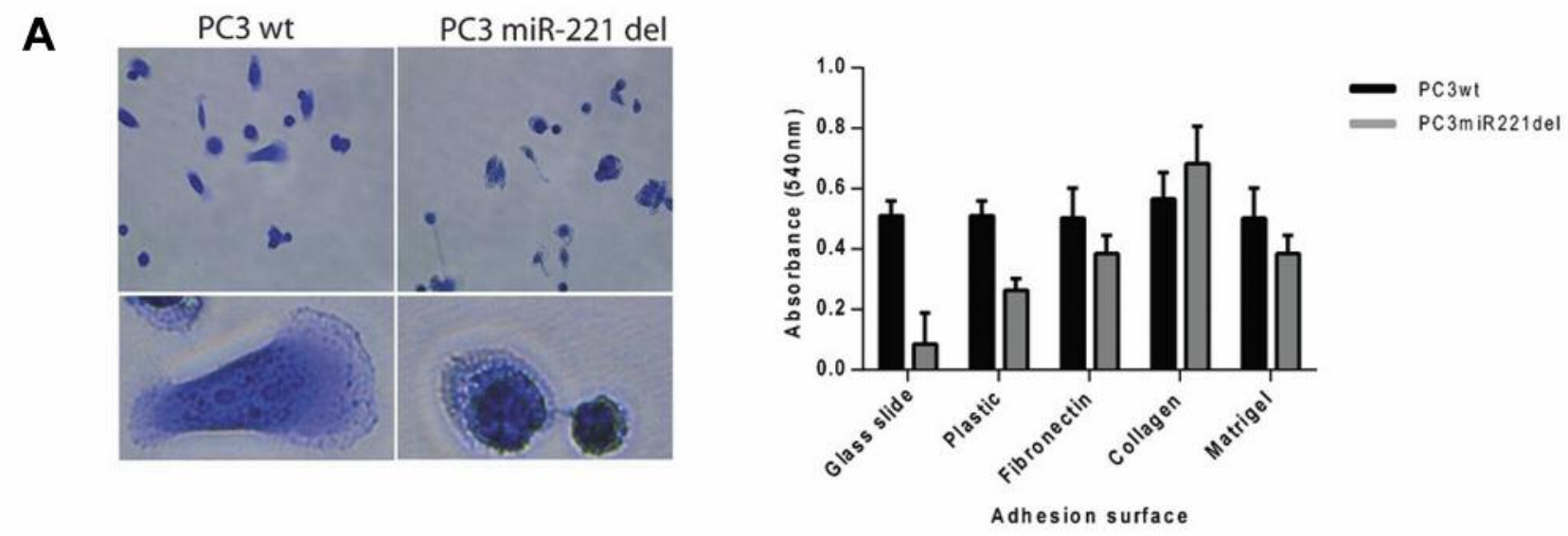

B
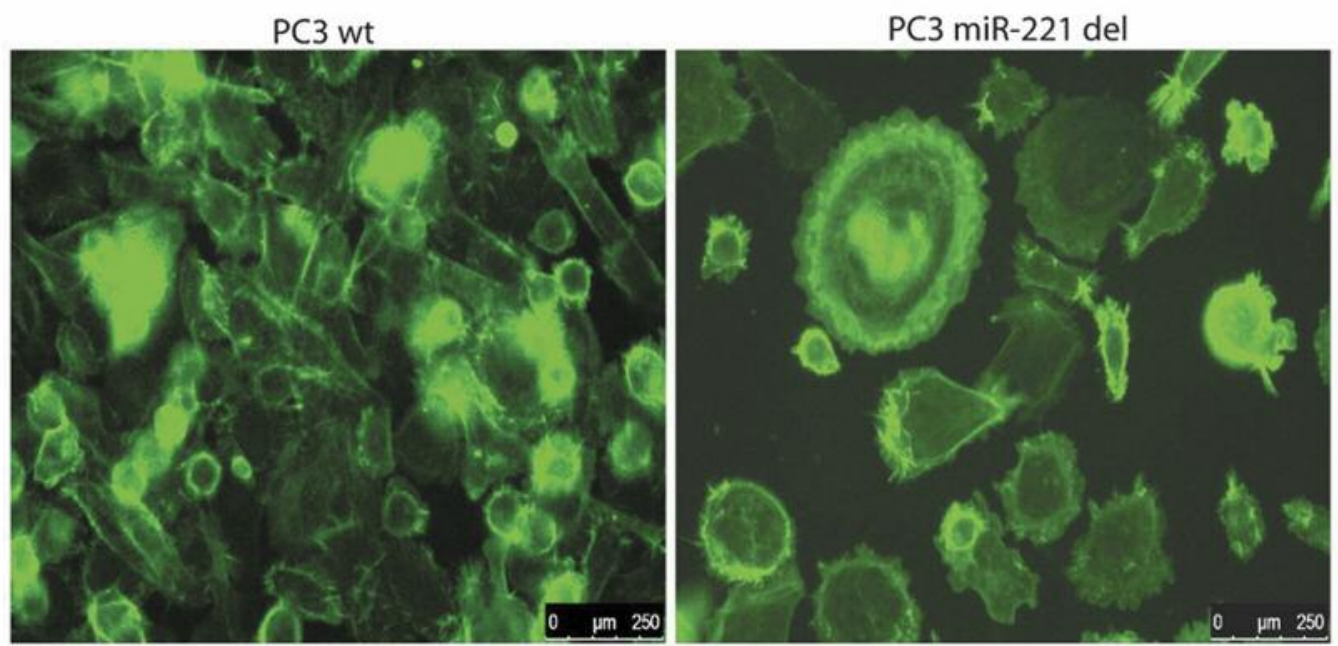

Figure 5. MiR-221 deletion affects cell adhesion and morphology. A) Photograph of PC $3^{\text {wt }}$ and PC3miR-22ldel cells allowed to adhere for 2 h on cell culture plastic dishes. Upper panel x10, lower panel x40 magnification. Boxplot (left) indicates the number of cells adhered to each type of coated surface after $2 \mathrm{~h}$ as measured by counting crystal violet stained cells. B) F-actin (Phalloidin-FITC conjugate) staining of PC $3^{\text {wt }}$ and PC $3^{m i R}$ 221 del cells after adhesion to cell culture plastic for $4 \mathrm{~h}$.

compared to PC $3^{\mathrm{wt}}$ cells, or any other prostate cell line in our panel (Figure 7A). DIRAS3 protein levels were also increased in these cells, as shown by western blotting (Figure 7B). DIRAS3 full length transcript (1.3kb coding and 3'UTR combined) was also increased in the PC $3^{\text {miR-221del }}$ cells as compared to the $\mathrm{PC} 3^{\mathrm{wt}}$ - as analysed by semi-quantitative PCR (Figure 7C).

We cloned the coding sequence of the DIRAS3 cDNA into pEF6-TOPO (Invitrogen) for mammalian cell ectopic expression. When we overexpressed this protein in $\mathrm{PC} 3^{\mathrm{wt}}$ cells (Figure 7D) we found that in a wound healing assay these cells showed very retarded movement and failure to close the wound entirely (Figure 7E). Additionally, DIRAS3 expressing cells became rounded and less adherent, and when stained with phalloidin for F-actin showed the same ring-like structure of F-actin fibres. Cells also showed no leading lamellipodia and cytoplasmic ruffling, as was previously indicative in the $\mathrm{PC} 3^{\text {miR-221del }}$ cells (Figure 7F). Additionally, upon ECIS analysis, DIRAS3 overexpression reduced the ability of the $\mathrm{PC} 3^{\mathrm{wt}}$ cells to produce a mature cell monolayer, with any electrical resistance (Figure 7G). After a wound was applied (via an electric field) the PC $3^{\text {wt }}$ cells overexpressing DIRAS3 failed to reproduce a monolayer with any electrical resistance (Figure 7H).

We then analysed the stability of the DIRAS3 UTR sequence in $\mathrm{PC}^{\mathrm{wt}}$ and $\mathrm{PC} 3^{\mathrm{miR}-221 \mathrm{del}}$ cells. We fused the 3'UTR sequence of DIRAS3 into the firefly luciferase of the pMirGlo reporter (Promega) (Figure 6). When transiently 

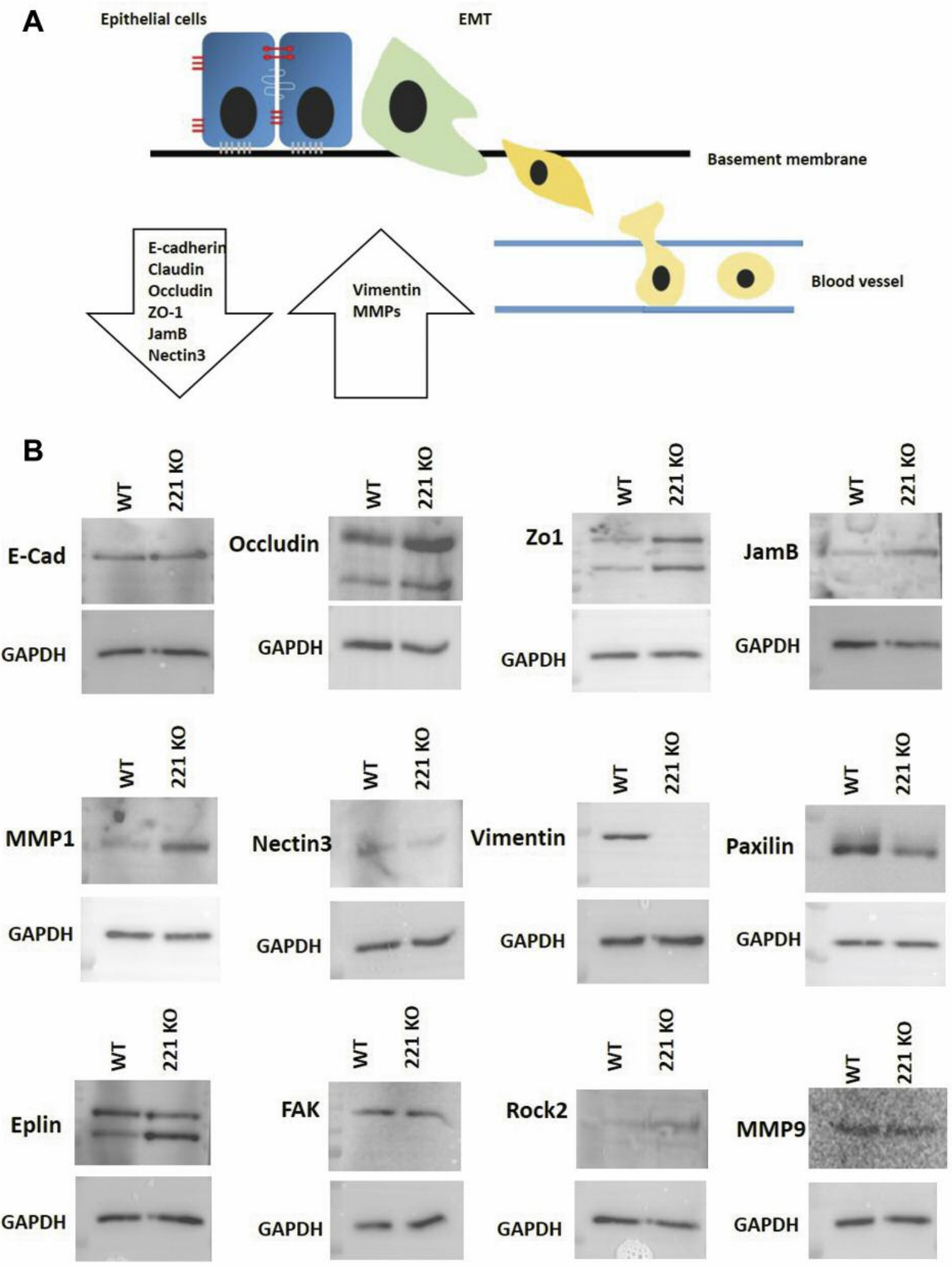

Figure 6. MiR-221 deletion alters components of the epithelial to mesenchymal transition (EMT) in PC3 cells. A) Schematic indicating the genes involved cell-cell adhesion, cell-surface adhesion and how they change during the EMT in cancer. B) Western blotting for various components of the EMT in PC3 wt and PC $3^{m i R-221 d e l}$ cells. Equal loading was verified by probing for GAPDH. 
Table II. Functional annotation results from the Ingenuity Pathway Analysis (IPA) software on the gene expression changes seen in PC3miR-221del cells, as detected by Ampliseq.

\begin{tabular}{lcc}
\hline Category & Functions annotation & $p$-Value \\
\hline Cardiovascular System Development, Cell-to-cell signaling and interaction & Adhesion of vascular endothelial cells & 0.001 \\
Cell-to-cell signaling and interaction & Binding of prostate cancer cell lines & 0.003 \\
Cell-to-cell signaling and interaction & Adhesion of prostate cancer cell lines & 0.005 \\
Cellular movement & Trans-endothelial migration of prostate cancer cell lines & 0.016 \\
Cell signaling, molecular transport, mineral metabolism & Mobilization of Ca $\mathrm{Ca}^{2+}$ & 0.026 \\
\hline
\end{tabular}

Table III. Top networks and diseases affected predicted from the Ingenuity Pathway Analysis (IPA) software on the gene expression changes seen in PC3miR-221del cells, as detected by Ampliseq.

\begin{tabular}{lcc}
\hline Molecules in network & Score & Top diseases and functions \\
\hline DMD,ESR2,HMGA1,IER2,JUN,JUNB, & & \\
MAPK9,NR3C2,PTGS2,TGFB1,TNF & 9 & Endocrine System Disorders, Gastrointestinal Disease, Inflammatory Disease \\
CHUK, CXCL12, CXCR4, RELA & 3 & Cell-To-Cell Signalling and Interaction, Cell Morphology, Cell-mediated Immune Response \\
GSK3B, SH3GLB1 & 1 & Cell Morphology, Cellular Function and Maintenance, Neurological Disease \\
BCL2, PTEN & 1 & Tissue Morphology, Cell Morphology, Cancer \\
CEBPB, HIPK2 & 1 & Cell-To-Cell Signalling and Interaction, Cellular Assembly and Organization, Cellular Compromise \\
DIRAS3, mir-221 & 1 & Cellular Development, Cellular Growth and Proliferation \\
BMP6, DKK1 & 1 & Cellular Development, Embryonic Development, Organismal Development \\
CFLAR, FOS & 1 & Cell Death and Survival, Nervous System Development and Function, Cancer \\
AGR2, CBX1, CDKN2A & 1 & Cancer, Cellular Development, Cellular Growth and Proliferation \\
BGLAP, PLAU, PREX1, SP3 & 1 & Digestive System Development and Function, Embryonic Development, Organismal Development \\
DDIT3, RHOC, TNFRSF10B, UACA & 1 & Cell Death and Survival, Digestive System Development and Function, Gastrointestinal Disease \\
\hline
\end{tabular}

transfected into $\mathrm{PC} 3^{\mathrm{wt}}$ or PC $3^{\text {miR-221del }}$ cells the stability and activity of the luciferase reporter was increased in the PC $3^{\mathrm{miR}-}$ 221 del cells. The DIRAS3 UTR showed a lower activity in both cell lines when compared to the empty vector (Figure 7I).

\section{Discussion}

MicroRNAs and non-coding RNAs modulate the transcriptome and have been found to be increasingly important regulators of several physiological and disease states. Mir-221 is described as an oncogenic microRNA. It can target several mRNAs, many of which have roles in migration, proliferation, and angiogenesis. However, its exact role and its effects on disease outcome or progression is under some debate. There appears to be a discrepancy between the observed in vitro effects of miR-221 on cancer cells and the clinical outcomes or risk factors for patients with cancer.

Other oncogenic miRs, e.g. miR-16 and 27a, were proportionally up-regulated with increased aggressiveness of the cell line, but miR-221 was seen to be very highly expressed in PC3 when compared to other prostate cell lines - being the second most highly expressed cellular miR. However, the less aggressive benign tissue-derived cell lines,
Figure 7. DIRAS3 is a target of MiR-221 and is more strongly expressed in PC3miR-221del cells. A) Q-PCR analysis of DIRAS3 expression in a panel of prostate cell lines. Expression was normalised to GAPDH, $\beta$ actin and RPL19. B) Western blot showing expression of DIRAS3 in $P C 3^{w t}$ and PC3miR-22ldel cells. GAPDH was probed on the same membrane as a control. C) Semi-quantitative PCR of DIRAS3-UTR (coding and UTR - $1.3 \mathrm{~kb}$ ) and GAPDH (500 bp). DIRAS3-UTR required 32 cycles, GAPDH required 24 cycles. D) Bar graph indicating the expression levels of DIRAS3 in PC $3^{w t}$ cells transfected with pEF6DIRAS3 to ectopically overexpress DIRAS3. E) Boxplot representing the $\%$ closure of a scratch (wound healing) assay of PC $3^{\text {wt }}$ cells either untreated, mock treated, transfected with either empty pEF6 or pEF6DIRAS3 cDNA, over 8 h.F) Photograph of PC3 cells either transfected with pEF6-Empty or pEF6-DIRAS3 cDNA for $24 \mathrm{~h}$ and stained for $F$ actin (Phalloidin-FITC conjugate) and nuclear DNA (DAPI) staining. Upper panel represents phase contrast microscopic image. Lower panel represents fluorescent channel imaging (merge). G) Graph indicating the electrical resistance of $P C 3^{w t}$ cells transfected with pEF6-DIRAS3 (or empty) adhering to the ECIS assay plate over $16 \mathrm{~h} . \mathrm{H}$ ) Recovery of the electrical resistance of PC ${ }^{w t}$ cell (transfected with PEF6-DIRAS3 or empty) of $20 \mathrm{~h}$ after the application of an electrical wounding at time $=0$. I) Schematic diagram of the empty luciferase reporter (pmiR-Glo) and the luciferase fused to DIRAS3 3'UTR (left panel) and luciferase activity from extracts of $P C 3^{w t}$ and $P C 3^{m i R-221 d e l}$ cells transfected with either pmiR-Glo Empty or pmiR-Glo-DIRAS3 3'UTR reporter plasmids for $24 \mathrm{~h}$ (right side). Data represents firefly luciferase activity over renilla luciferase (constitutive) activity expressed from the same plasmid. 


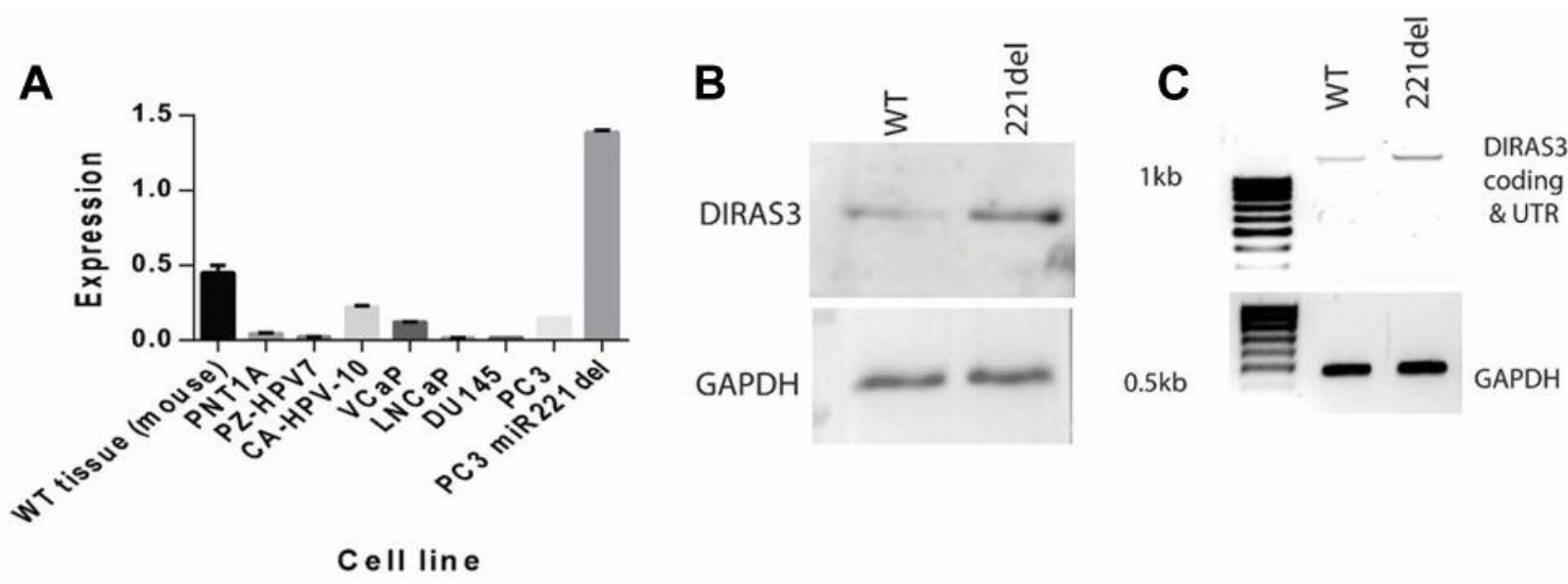

D

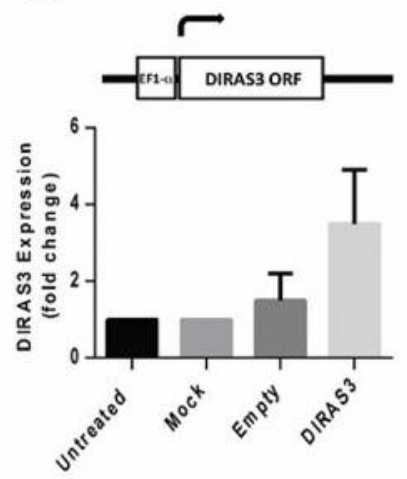

G

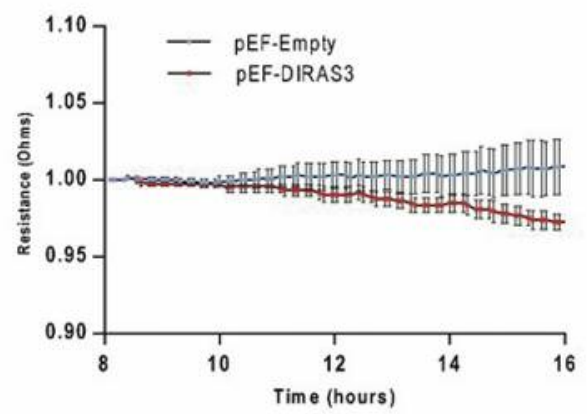

I

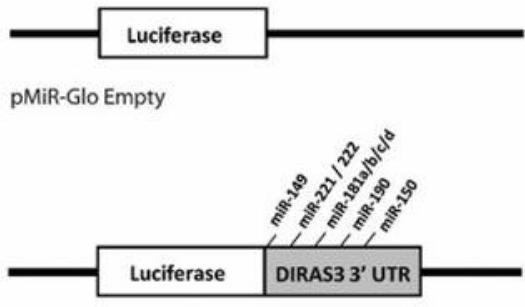

PMIR-Glo DIRAS3 UTR
E

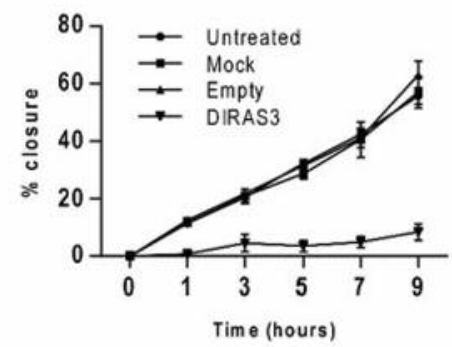

H
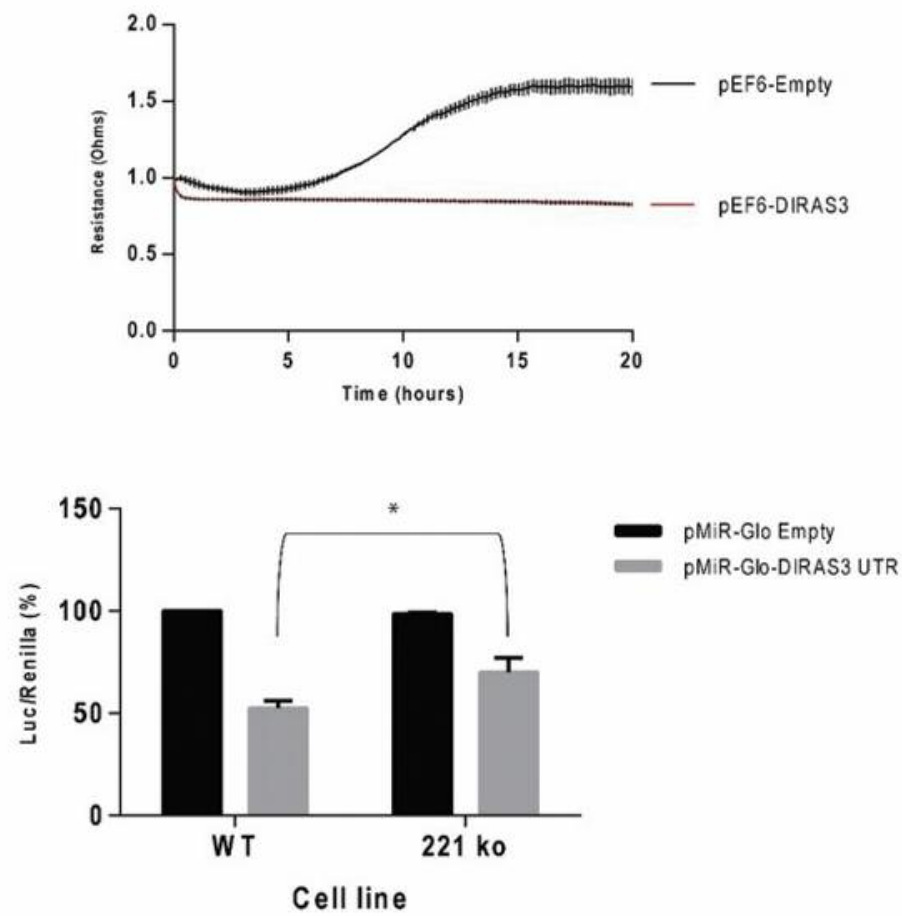
e.g. PNT1A, PZ-HPV7, and low-grade prostate cancer-derived CA-HPV-10, did show increased miR-221 expression as compared to the highly aggressive late-stage representative cell lines $\mathrm{LNCaP}, \mathrm{VCaP}$ and Du145. This may in part explain why the in vitro and clinical data on miR-221 are not in agreement, as this particular miR did not correlate with aggressiveness across our cell line panel and was mostly unique to PC3. PC3 cells themselves have been singled out as potentially being a sub-category of prostate cancer and share some characteristics of prostatic small cell neuroendocrine carcinoma (SCNC), but this is still under some debate.

Therefore, we set out to determine the role of miR-221, which was very highly expressed in the androgen independent and aggressive cell line PC 3. Rather than using modified artificially transfected oligos to modulate the levels and activity of miRs which may generate off-target effects e.g. RNA oligos can be potent inducers of interferons (IFNs) and inflammatory cytokines in vitro. Therefore, we decided to utilise a CRISPR/Cas9 method to delete the bases encoding for miR-221, according to the methods set out by Ho et al. (35), Chang et al. (36) and Zhao et al. (37). Cas9 alone may incorporate double strand breaks and small indels in the genome, which may not be sufficient to knockout the entire function of a microRNA. Therefore, we utilised an additional homology recombination-based selection system by designing a donor vector where the target mir-221 bases were replaced by RFP and puromycin resistance genes.

Normal male cells would have only 1 copy of the X chromosome upon which miR-221 is located. However, since PC 3 cells are near-triploid with a modal number of 62 chromosomes (38), we were surprised by the efficiency of the CRISPR procedure to remove mir-221 to almost undetectable levels. We cannot rule out that additional copies of the $\mathrm{X}$ chromosome region that may have remained unmodified or with indels, but the novel genomic recombination of plasmid DNA was confirmed by PCR. Indels may not be detected by qPCR methods utilising a sequence-specific probe. Additionally, we cannot rule out the global effects of mir-221 knock-out on other miRs, but the levels of the strongly expressed miR-16 did not change significantly when analysed by qPCR.

Ampliseq analysis of global gene expression changes of over 20,000 genes in response to miR-221 knock-out resulted in 646 significantly down-regulated genes and 534 upregulated genes $(-/+2$-fold change, $p=0.05)$. No significant correlation could be deduced between the down-regulated genes and miR-221 validated targets - as analysed by microrna.org, mirDB, Targetscan and Targetminer websites. Although it should be noted that Ampliseq does not measure 3'UTR regions and their stability. This would indicate that changing this microRNA may have significant global effects in the cell. Pathway analysis (IPA) revealed that cell-cell adhesion and migration were the most affected pathways.
The cell cycle regulatory pathways did not score highly as being relevant. The effect of miR-221 on cell growth was first examined as miR-221 had been reported to target CDKN1B/p27. The growth of PC $3^{\text {miR-221del }}$ cells was slower than wild type cells, and the \% of cells remaining in S phase was greater after 7 days of growth, indicating they had not yet reached confluence and contact inhibition. We then analysed the gene expression of various cell cycle genes $e . g$. p21, p27 and the MCM family. There was a significant reduction of replication related genes e.g. MCM5 and an increase in the cell-cycle inhibitor genes p21 and p 27 - thus, agreeing with the literature. However, the effects on p27 were not as significant as for $\mathrm{p} 21$.

The main characteristic differences in the PC $3^{\text {miR-221del }}$ cell line was in their adhesion and motility. The deletion of miR-221 reduced adhesion, motility and invasion in our assays. In the wound healing assay, there appeared to be a delay in wound closure of around $2 \mathrm{~h}$, but after which wound closure velocity appeared the same as the parental cells. The ECIS assays also showed a delayed production of a viable monolayer. This would indicate that when cell-cell contact inhibition was removed i.e. a wound, there was a delay in either - the detection of, or response to - a loss of cell-cell contact inhibition. Upon western blotting for markers of EMT and adhesion, the intermediate filament protein vimentin was strongly down-regulated. Vimentin contributes to EMT by mediating cytoskeletal organisation and is associated with cancer invasion and poor prognosis in several cancer types including breast and prostate $(39,40)$. Previously, Stinson et al. have shown that overexpression of miR-221 in breast cancer cells could decrease epithelialspecific genes and increase the expression of mesenchymalspecific genes $(41,42)$ e.g. E-cadherin and vimentin respectively. Eplin- $\alpha$, a gene found frequently lost during EMT $(43,44)$, was up-regulated in PC $3^{\text {miR-221del }}$ cells.

One of the main genes predicted to be affected and to affect downstream gene expression was the DIRAS3 tumour suppressor. DIRAS3 is a GTPase belonging to the Ras superfamily and shares 50-60\% homology with Ras and Rap, two other small GTP binding proteins, whose expression is reported to be reduced in $70 \%$ of invasive breast cancers (45, $46)$ and $60 \%$ of ovarian cancers (47-49). DIRAS3 expression was markedly increased in $\mathrm{PC} 3^{\mathrm{miR}-221 \mathrm{del}}$ cells at gene and protein levels. Ectopic overexpression of DIRAS3 cDNA in PC $3 w t$ cells greatly reduced their ability to close a wound in the wound healing assay (\& ECIS), and cells became rounded up and detached from the substrate forming large rounded cells with F-actin fibres, similar to those seen in PC $3^{\text {miR-221del }}$ cells. This would indicate a phenotypic mirroring of miR-221 loss and DIRAS3 expression. Additionally, the full-length mRNA (coding and UTR) expression was increased in PC $3^{\text {miR-221del }}$ cells and the luciferase-fused construct showed an increased activity in the PC $3^{\text {miR-221del }}$ cells; this would 
indicate that DIRAS3 is indeed a target of mir-221 (\&miR222). An inverse correlation between low DIRAS3 and high miR-221/222 levels has been shown in prostate cancer tissues, with a more aggressive tendency (25). DIRAS3 has important roles in inhibiting cell proliferation and migration whilst promoting apoptosis. It can also promote autophagy and induce tumour dormancy (50). The cellular morphology changes in PC3 cells by DIRAS3 overexpression and the inhibition of invasion have been previously demonstrated (51).

\section{Conclusion}

The role of miR-221 in PCa has shown stark differences to that observed in other types of cancer, with an apparent discrepancy between in vitro and clinical studies. Here, in a panel of PCa cell lines, miR-221 was seen to be reduced across a panel of prostate cancer cell lines increasing in grade, agreeing with clinical data. However, for the highly aggressive PC3 cell line, miR-221 expression was much higher and its deletion from the genome caused reduction in cell growth, an inhibition or change in cell adhesion, and a reversal of several EMT markers. This would indicate that miR-221 has a very complex role in PCa. MiR-221 may mediate changes in cell-cell adhesion which may influence cancer cells dissociating from the primary tumour mass or influence metastatic cell adhesion to a distant site.

\section{Conflicts of Interest}

The Authors declare that they have no competing interests regarding this study.

\section{Funding}

The Cardiff University - Peking University Cancer Institute.

\section{Authors' Contributions}

Experiments: Alwyn Dart, Ben Lanning, Sarah Koushyar; Writing: Alwyn Dart, Wenguo Jiang.

\section{References}

1 Ferlay J, Autier P, Boniol M, Heanue M, Colombet M and Boyle $\mathrm{P}$ : Estimates of the cancer incidence and mortality in Europe in 2006. Ann Oncol 18(3): 581-592, 2007. PMID: 17287242. DOI: 10.1093/annonc/mdl498

2 Siegel R, Naishadham D and Jemal A: Cancer statistics, 2013. CA Cancer J Clin 63(1): 11-30, 2013. PMID: 23335087. DOI: $10.3322 /$ caac. 21166

3 Siegel RL, Miller KD and Jemal A: Cancer statistics, 2016. CA Cancer J Clin 66(1): 7-30, 2016. PMID: 26742998. DOI: $10.3322 /$ caac. 21332

4 Farazi TA, Hoell JI, Morozov P and Tuschl T: MicroRNAs in human cancer. Adv Exp Med Biol 774: 1-20, 2013. DOI: 10.1007/978-94-007-5590-1_1
5 Munker R and Calin GA: MicroRNA profiling in cancer. Clin Sci (Lond) 121(4): 141-158, 2011. PMID: 21526983. DOI: 10.1042/CS20110005

6 Lee RC, Feinbaum RL and Ambros V: The C. elegans heterochronic gene lin-4 encodes small RNAs with antisense complementarity to lin-14. Cell 75(5): 843-854, 1993. PMID: 8252621. DOI: 10.1016/0092-8674(93)90529-y

7 Wightman B, Ha I and Ruvkun G: Posttranscriptional regulation of the heterochronic gene lin-14 by lin- 4 mediates temporal pattern formation in C. elegans. Cell 75(5): 855-862, 1993. PMID: 8252622. DOI: 10.1016/0092-8674(93)90530-4

8 Guo H, Ingolia NT, Weissman JS and Bartel DP: Mammalian microRNAs predominantly act to decrease target mRNA levels. Nature 466(7308): 835-840, 2010. PMID: 20703300. DOI: 10.1038/nature09267

9 Chen YY, Ho HL, Lin SC, Ho TD and Hsu CY: Upregulation of miR-125b, miR-181d, and miR-221 Predicts Poor Prognosis in MGMT Promoter-Unmethylated Glioblastoma Patients. Am J Clin Pathol 149(5): 412-417, 2018. PMID: 29538610. DOI: 10.1093/ajcp/aqy008

$10 \mathrm{Li} \mathrm{W}$, Guo F, Wang P, Hong S and Zhang C: miR-221/222 confers radioresistance in glioblastoma cells through activating Akt independent of PTEN status. Curr Mol Med 14(1): 185-195, 2014. PMID: 24295494. DOI: 10.2174/156652401 366613 1203103147

11 Dai L, Wang Y, Chen L, Zheng J, Li J and Wu X: MiR-221, a potential prognostic biomarker for recurrence in papillary thyroid cancer. World J Surg Oncol 15(1): 11, 2017. PMID: 28061868. DOI: 10.1186/s12957-016-1086-Z

12 Chen WX, Hu Q, Qiu MT, Zhong SL, Xu JJ, Tang JH and Zhao JH: miR-221/222: promising biomarkers for breast cancer. Tumour Biol 34(3): 1361-1370, 2013. PMID: 23529451. DOI: 10.1007/s13277-013-0750-y

$13 \mathrm{Li}$ J, Wang Y, Yu W, Chen J and Luo J: Expression of serum miR-221 in human hepatocellular carcinoma and its prognostic significance. Biochem Biophys Res Commun 406(1): 70-73, 2011. PMID: 21295551. DOI: 10.1016/j.bbrc.2011.01.111

14 Fu X, Wang Q, Chen J, Huang X, Chen X, Cao L, Tan H, Li W, Zhang L, Bi J, Su Q and Chen L: Clinical significance of miR221 and its inverse correlation with $\mathrm{p}^{27 \mathrm{Kip}^{1}}$ in hepatocellular carcinoma. Mol Biol Rep 38(5): 3029-3035, 2011. PMID: 20146005. DOI: $10.1007 / \mathrm{s} 11033-010-9969-5$

15 Yamashita R, Sato M, Kakumu T, Hase T, Yogo N, Maruyama E, Sekido Y, Kondo M and Hasegawa Y: Growth inhibitory effects of miR-221 and miR-222 in non-small cell lung cancer cells. Cancer Med 4(4): 551-564, 2015. PMID: 25641933. DOI: $10.1002 /$ cam 4.412

16 Zhu Y, Li T, Chen G, Yan G, Zhang X, Wan Y, Li Q, Zhu B and Zhuo W: Identification of a serum microRNA expression signature for detection of lung cancer, involving miR-23b, miR221, miR-148b and miR-423-3p. Lung Cancer 114: 6-11, 2017. PMID: 29173767. DOI: 10.1016/j.lungcan.2017.10.002

17 Spahn M, Kneitz S, Scholz CJ, Stenger N, Rüdiger T, Ströbel P, Riedmiller H and Kneitz B: Expression of microRNA-221 is progressively reduced in aggressive prostate cancer and metastasis and predicts clinical recurrence. Int J Cancer 127(2): 394-403, 2010. PMID: 19585579. DOI: 10.1002/ijc.24715

18 Goto Y, Kojima S, Nishikawa R, Kurozumi A, Kato M, Enokida H, Matsushita R, Yamazaki K, Ishida Y, Nakagawa M, Naya Y, Ichikawa $\mathrm{T}$ and Seki $\mathrm{N}$ : MicroRNA expression signature of 
castration-resistant prostate cancer: the microRNA-221/222 cluster functions as a tumour suppressor and disease progression marker. Br J Cancer 113(7): 1055-1065, 2015. PMID: 26325107. DOI: $10.1038 /$ bjc .2015 .300

19 Gordanpour A, Stanimirovic A, Nam RK, Moreno CS, Sherman C, Sugar L and Seth A: miR-221 Is down-regulated in TMPRSS2:ERG fusion-positive prostate cancer. Anticancer Res 31(2): 403-410, 2011. PMID: 21378318.

20 Kneitz B, Krebs M, Kalogirou C, Schubert M, Joniau S, van Poppel H, Lerut E, Kneitz S, Scholz CJ, Ströbel P, Gessler M, Riedmiller H and Spahn M: Survival in patients with high-risk prostate cancer is predicted by miR-221, which regulates proliferation, apoptosis, and invasion of prostate cancer cells by inhibiting IRF2 and SOCS3. Cancer Res 74(9): 2591-2603, 2014. PMID: 24607843. DOI: 10.1158/0008-5472.CAN-13-1606

21 Porkka KP, Pfeiffer MJ, Waltering KK, Vessella RL, Tammela TL and Visakorpi T: MicroRNA expression profiling in prostate cancer. Cancer Res 67(13): 6130-6135, 2007. PMID: 17616669. DOI: 10.1158/0008-5472.CAN-07-0533

22 Szczyrba J, Löprich E, Wach S, Jung V, Unteregger G, Barth S, Grobholz R, Wieland W, Stöhr R, Hartmann A, Wullich B and Grässer F: The microRNA profile of prostate carcinoma obtained by deep sequencing. Mol Cancer Res 8(4): 529-538, 2010. PMID: 20353999. DOI: 10.1158/1541-7786.MCR-09-0443

23 Ambs S, Prueitt RL, Yi M, Hudson RS, Howe TM, Petrocca F, Wallace TA, Liu CG, Volinia S, Calin GA, Yfantis HG, Stephens $\mathrm{RM}$ and Croce CM: Genomic profiling of microRNA and messenger RNA reveals deregulated microRNA expression in prostate cancer. Cancer Res 68(15): 6162-6170, 2008. PMID: 18676839. DOI: 10.1158/0008-5472.CAN-08-0144

24 Wach S, Nolte E, Szczyrba J, Stöhr R, Hartmann A, Ørntoft T, Dyrskjøt L, Eltze E, Wieland W, Keck B, Ekici AB, Grässer F and Wullich B: MicroRNA profiles of prostate carcinoma detected by multiplatform microRNA screening. Int J Cancer 130(3): 611-621, 2012. PMID: 21400514. DOI: 10.1002/ ijc. 26064

25 Lin D, Cui F, Bu Q and Yan C: The expression and clinical significance of GTP-binding RAS-like 3 (ARHI) and microRNA 221 and 222 in prostate cancer. J Int Med Res 39(5): 1870-1875, 2011. PMID: 22117988. DOI: 10.1177/147323001103900530

26 Zheng C, Yinghao S and Li J: MiR-221 expression affects invasion potential of human prostate carcinoma cell lines by targeting DVL2. Med Oncol 29(2): 815-822, 2012. PMID: 21487968. DOI: 10.1007/s12032-011-9934-8

27 Yang X, Yang Y, Gan R, Zhao L, Li W, Zhou H, Wang X, Lu J and Meng QH: Down-regulation of mir-221 and mir-222 restrain prostate cancer cell proliferation and migration that is partly mediated by activation of SIRT1. PLoS One 9(6): e98833, 2014. PMID: 24892674. DOI: 10.1371/journal.pone.0098833

28 Sun T, Yang M, Kantoff P and Lee GS: Role of microRNA-221/222 in cancer development and progression. Cell Cycle $8(15)$ : 2315-2316, 2009. PMID: 19625765. DOI: 10.4161/cc.8.15.9221

29 Sun T, Wang Q, Balk S, Brown M, Lee GS and Kantoff P: The role of microRNA-221 and microRNA-222 in androgenindependent prostate cancer cell lines. Cancer Res 69(8): 33563363, 2009. PMID: 19351832. DOI: 10.1158/0008-5472.CAN08-4112

30 Sun T, Wang X, He HH, Sweeney CJ, Liu SX, Brown M, Balk S, Lee GS and Kantoff PW: MiR-221 promotes the development of androgen independence in prostate cancer cells via downregulation of HECTD2 and RAB1A. Oncogene 33(21): 2790-2800, 2014. PMID: 23770851. DOI: 10.1038/onc.2013.230

31 Mercatelli N, Coppola V, Bonci D, Miele F, Costantini A, Guadagnoli M, Bonanno E, Muto G, Frajese GV, De Maria R, Spagnoli LG, Farace MG and Ciafrè SA: The inhibition of the highly expressed miR-221 and miR-222 impairs the growth of prostate carcinoma xenografts in mice. PLoS One 3(12): e4029, 2008. PMID: 19107213. DOI: 10.1371/journal.pone.0004029

32 Galardi S, Mercatelli N, Giorda E, Massalini S, Frajese GV, Ciafrè SA and Farace MG: miR-221 and miR-222 expression affects the proliferation potential of human prostate carcinoma cell lines by targeting p27Kip1. J Biol Chem 282(32): 2371623724, 2007. PMID: 17569667. DOI: 10.1074/jbc.M701805200

33 Gui B, Hsieh CL, Kantoff PW, Kibel AS and Jia L: Androgen receptor-mediated downregulation of microRNA-221 and -222 in castration-resistant prostate cancer. PLoS One 12(9): e0184166, 2017. PMID: 28886115. DOI: 10.1371/journal.pone. 0184166

34 Tai S, Sun Y, Squires JM, Zhang H, Oh WK, Liang CZ and Huang J: PC3 is a cell line characteristic of prostatic small cell carcinoma. Prostate 71(15): 1668-1679, 2011. PMID: 21432867. DOI: $10.1002 /$ pros.21383

35 Ho TT, Zhou N, Huang J, Koirala P, Xu M, Fung R, Wu F and Mo YY: Targeting non-coding RNAs with the CRISPR/Cas9 system in human cell lines. Nucleic Acids Res 43(3): e17, 2015. PMID: 25414344. DOI: 10.1093/nar/gku 1198

36 Chang $\mathrm{H}$, Yi $\mathrm{B}$, Ma R, Zhang $\mathrm{X}$, Zhao $\mathrm{H}$ and $\mathrm{Xi} \mathrm{Y}$ : CRISPR/cas9, a novel genomic tool to knock down microRNA in vitro and in vivo. Sci Rep 6: 22312, 2016. PMID: 26924382. DOI: $10.1038 /$ srep22312

37 Zhao Y, Dai Z, Liang Y, Yin M, Ma K, He M, Ouyang H and Teng CB: Sequence-specific inhibition of microRNA via CRISPR/CRISPRi system. Sci Rep 4: 3943, 2014. PMID: 24487629. DOI: 10.1038/srep03943

38 Ohnuki Y, Marnell MM, Babcock MS, Lechner JF and Kaighn ME: Chromosomal analysis of human prostatic adenocarcinoma cell lines. Cancer Res 40(3): 524-534, 1980. PMID: 7471073.

39 Lehtinen L, Ketola K, Mäkelä R, Mpindi JP, Viitala M, Kallioniemi $\mathrm{O}$ and Iljin K: High-throughput RNAi screening for novel modulators of vimentin expression identifies MTHFD2 as a regulator of breast cancer cell migration and invasion. Oncotarget 4(1): 48-63, 2013. PMID: 23295955. DOI: 10.18632/ oncotarget.756

40 Liu CY, Lin HH, Tang MJ and Wang YK: Vimentin contributes to epithelial-mesenchymal transition cancer cell mechanics by mediating cytoskeletal organization and focal adhesion maturation. Oncotarget 6(18): 15966-15983, 2015. PMID: 25965826. DOI: 10.18632 /oncotarget.3862

41 Stinson S, Lackner MR, Adai AT, Yu N, Kim HJ, O'Brien C, Spoerke J, Jhunjhunwala S, Boyd Z, Januario T, Newman RJ, Yue P, Bourgon R, Modrusan Z, Stern HM, Warming S, de Sauvage FJ, Amler L, Yeh RF and Dornan D: miR-221/222 targeting of trichorhinophalangeal 1 (TRPS1) promotes epithelial-tomesenchymal transition in breast cancer. Sci Signal 4(186): pt5, 2011. PMID: 21868360. DOI: 10.1126/scisignal. 2002258

42 Stinson S, Lackner MR, Adai AT, Yu N, Kim HJ, O'Brien C, Spoerke J, Jhunjhunwala S, Boyd Z, Januario T, Newman RJ, Yue P, Bourgon R, Modrusan Z, Stern HM, Warming S, de Sauvage FJ, Amler L, Yeh RF and Dornan D: TRPS1 targeting by miR$221 / 222$ promotes the epithelial-to-mesenchymal transition in 
breast cancer. Sci Signal 4(177): ra41, 2011. PMID: 21673316 DOI: $10.1126 /$ scisignal.2001538

43 Sanders AJ, Martin TA, Ye L, Mason MD and Jiang WG: EPLIN is a negative regulator of prostate cancer growth and invasion. $\mathrm{J}$ Urol 186(1): 295-301, 2011. PMID: 21600601. DOI: 10.1016/ j.juro.2011.03.038

44 Zhang S, Wang X, Osunkoya AO, Iqbal S, Wang Y, Chen Z, Müller S, Chen Z, Josson S, Coleman IM, Nelson PS, Wang YA, Wang R, Shin DM, Marshall FF, Kucuk O, Chung LW, Zhau HE and $\mathrm{Wu} \mathrm{D}$ : EPLIN downregulation promotes epithelialmesenchymal transition in prostate cancer cells and correlates with clinical lymph node metastasis. Oncogene 30(50): 49414952, 2011. PMID: 21625216. DOI: 10.1038/onc.2011.199

45 Li Y, Shi L, Han C, Wang Y, Yang J, Cao C and Jiao S: Effects of ARHI on cell cycle progression and apoptosis levels of breast cancer cells. Tumour Biol 33(5): 1403-1410, 2012. DOI: 10.1007/s13277-012-0388-1

46 Li Y, Liu M, Zhang Y, Han C, You J, Yang J, Cao C and Jiao S: Effects of ARHI on breast cancer cell biological behavior regulated by microRNA-221. Tumour Biol 34(6): 3545-3554, 2013. PMID: 23801152. DOI: 10.1007/s13277-013-0933-6

47 Li J, Cui G, Sun L, Wang SJ, Li YL, Meng YG, Guan Z, Fan WS, Li LA, Yang YZ, You YQ, Fu XY, Yan ZF and Huang K: STAT3 acetylation-induced promoter methylation is associated with downregulation of the ARHI tumor-suppressor gene in ovarian cancer. Oncol Rep 30(1): 165-170, 2013. PMID: 23604529. DOI: $10.3892 /$ or.2013.2414
48 Li J, Cui G, Sun L, Wang SJ, Tian S, Guan Z, Fan WS, Yan ZF, Yang YZ, You YQ, Fu XY, Li LA, Huang K, Li YL and Meng YG: ARHI overexpression induces epithelial ovarian cancer cell apoptosis and excessive autophagy. Int J Gynecol Cancer 24(3): 437-443, 2014. PMID: 24476894. DOI: 10.1097/IGC.0000 000000000065

49 Badgwell DB, Lu Z, Le K, Gao F, Yang M, Suh GK, Bao JJ, Das P, Andreeff M, Chen W, Yu Y, Ahmed AA, SL Liao W and Bast RC Jr: The tumor-suppressor gene ARHI (DIRAS3) suppresses ovarian cancer cell migration through inhibition of the Stat 3 and FAK/Rho signaling pathways. Oncogene 31(1): 68-79, 2012. PMID: 21643014. DOI: 10.1038/onc.2011.213

$50 \mathrm{Lu} \mathrm{Z}$ and Bast RC: The tumor suppressor gene ARHI (DIRAS3) inhibits ovarian cancer cell migration through multiple mechanisms. Cell Adh Migr 7(2): 232-236, 2013. PMID: 23357870. DOI: $10.4161 /$ cam.23648

51 Chen Y, Zaman MS, Deng G, Majid S, Saini S, Liu J, Tanaka Y and Dahiya: MicroRNAs 221/222 and genistein-mediated regulation of ARHI tumor suppressor gene in prostate cancer. Cancer Prev Res (Phila) 4(1): 76-86, 2011. PMID: 21071579. DOI: 10.1158/1940-6207.CAPR-10-0167

Received June 28, 2019

Revised July 15, 2019

Accepted July 18, 2019 